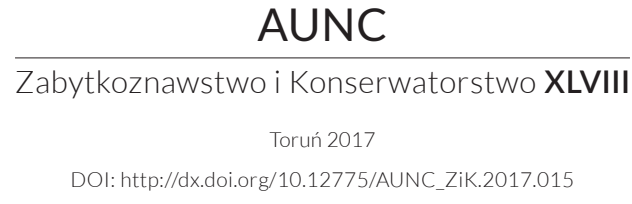

\title{
Materiały do zabezpieczania i regeneracji szylkretu
}

\author{
ANDRZEJ PODGÓRSKI \\ Zakład Konserwacji Elementów i Detali Architektonicznych, \\ Wydział Sztuk Pięknych, UMK w Toruniu \\ e-mail: andi@umk.pl \\ SONIA STAWOWSKA

\section{ALINA TOMASZEWSKA-SZEWCZYK} \\ Zakład Konserwacji Elementów i Detali Architektonicznych, \\ Wydział Sztuk Pięknych, UMK w Toruniu \\ e-mail: alina.tomaszewska-szewczyk@umk.pl
}

Keys words: tortoiseshell, conservation, protection coating, regeneration Słowa kluczowe: szylkret, konserwacja, zabezpieczanie, regeneracja

\begin{abstract}
Materials for tortoiseshell protection coating and its regeneration

Tortoiseshell has always been widely used in crafts. Its preparation and handling during the artistic process is a unique procedure, characteristic only of this material. The conservation of tortoiseshell has never been approached as an individual subject, being usually grouped with other materials - similar in structure (horn) or visually (amber). The most pressing conservation problem of tortoiseshell is its proneness to deformation and destruction of the surface. The main goal of the undertaken research is to establish the best way of preservation of the surface. The studies have been conducted on fragments of tortoiseshell and aquatic turtle scutes. The following materials have been used: sweet almond oil, argan oil, castor oil, amber oil, hydrolysed keratin, urea, Olaplex, acrylic resin Paraloid B-72. In order to determine the resistance of those substances to aging process, prepared samples were exposed
\end{abstract}


to rapid changes of humidity in climatic chamber. All changes on the surface were observed and recorded using organoleptic examination, optical microscope, scanning electron microscope and atomic force microscopy. Apart from general resistance to aging, analysed features included changes in colour, glossiness, surface destruction, elasticity and the degree of filling small crevices by the researched substances. The best coating has been obtained from seed oils. They highly increased the sample's elasticity and its mechanical resistance. The surface smoothness acquired with seed oils was also the most satisfying after climatic chamber exposure.

\begin{abstract}
Abstrakt
Szylkret był materiałem szeroko wykorzystywanym w rzemiośle artystycznym. Jego przygotowanie i obróbka wymagają specyficznego, indywidualnego procesu technologicznego. Jednak pod względem konserwatorskim szylkret do tej pory nie był traktowany odrębnie, lecz grupowany z materiałami zbliżonymi pod względem budowy (róg) lub wizualnym (bursztyn). Głównym zagadnieniem konserwatorskim dla tego materiału jest zmaganie się ze zmianami powierzchniowymi i deformacją, które są najczęściej spotykaną formą zniszczeń na obiektach szylkretowych. Celem badań jest wytypowanie środków do powierzchniowego zabezpieczania szylkretu. Analizy przeprowadzono na fragmentach szylkretu oraz na łuskach żółwia wodnego. Sprawdzono skuteczność działania następujących preparatów: olejów migdałowego, arganowego, rycynowego i bursztynowego, hydrolizowanej keratyny, mocznika oraz handlowych środków Olaplex i Paraloid B-72. Nasycone próbki poddano działaniu zmiennych warunków wilgotnościowych. Do oceny zmian zastosowano badanie organoleptyczne, a także analizy pod mikroskopem optycznym, skaningowym mikroskopem elektronowym oraz mikroskopem sił atomowych. Najlepszym działaniem zabezpieczającym wykazały się naturalne oleje roślinne: migdałowy, arganowy i rycynowy.
\end{abstract}

Utrata poleru i przejrzystości, deformacje, kruchość, spękania i rozwarstwienie - oto zmiany, jakim podlegają wytwory szylkretowe narażone na nieodpowiednie warunki przechowywania bądź użytkowania ${ }^{1}$.

Sposoby przywracania pierwotnych właściwości szylkretu, cofnięcia w znacznym stopniu niektórych powstałych zmian, omawia między innymi Harold J. Plenderleith² ${ }^{2}$ Według niego powierzchnia szylkretu powinna

1 Szerzej o właściwościach szylkretu, technologii, technikach zdobniczych i niszczeniu zob. Andrzej Podgórski i Alina Tomaszewska-Szewczyk, „Szylkret, bioorganiczny materiał w rzemiośle artystycznym - zagadnienia z zakresu materiałoznawstwa, technologii i stosowanych technik dekoracyjnych oraz niszczenia”, Acta Universitatis Nicolai Copernici, Zabytkoznawstwo i Konserwatorstwo 46 (2015): 449-470, DOI: http://dx.doi.org/10.12775/ AUNC_ZiK.2015.018.

2 H[arold] J. Plenderleith, The Conservation of Antiquities and Works of Art. Treatment, Repair, and Restoration (London: Oxford University Press, 1962), 155. 
być oczyszczana tak jak kość słoniowa, z uwzględnieniem stanu zachowania materiału przy doborze zabiegów. Jeśli obiekt jest w dobrej kondycji, należy użyć wody z detergentem oraz szczoteczki (tu Plenderleith odradza stosowanie gąbki lub ściereczki), a po zabiegu natychmiast osuszyć powierzchnię. Natomiast gdy obiekt utracił poler lub widoczne są spękania, między myciem a osuszaniem zaleca kilkakrotne przetarcie powierzchni alkoholem. Plenderleith przedstawia metody konsolidacji przede wszystkim dla rogu, a wskazanym środkiem jest poli(octan winylu).

Metodę kompleksowej konserwacji szylkretu podaje również Władysław Ślesiński ${ }^{3}$. Do oczyszczania proponuje użycie gąbek lub tkanin nasyconych wodą, także z niewielkim dodatkiem neutralnego mydła, a po zabiegu niezwłoczne osuszenie powierzchni. Olej migdałowy, czyli środek stosowany przy wytwarzaniu przedmiotów z szylkretu, zaleca do „odświeżania” ich powierzchni - przy czym niewątpliwie ma na myśli nasycenie barwne, natomiast olej kopytkowy do przywracania im transparentności. Efekty te można osiągnąć również przez polerowanie mechanicznym różem polerskim, mączką pumeksową lub jej mieszaniną z węglem drzewnym, a w trudno dostępnych miejscach patyczkami z drewna olchowego. Ślesiński wzmiankuje też o możliwości stosowania alkoholowych roztworów szelaku. Deformacje zaleca usuwać w gorącym oleju lnianym, gotującej się wodzie lub nad parą wodną.

Według Janet M Cronyn ${ }^{4}$ zabiegi konsolidacji szylkretu powinny być przeprowadzane analogicznie do działań przy bursztynie albo gagacie. Do poprawienia właściwości optycznych poleca użycie oleju bursztynowego lub wosku.

W Victoria and Albert Museum przeprowadzono konserwację szylkretowej oprawy „Psalmów” Dawida wydanych przez Clementa Marota w 1658 roku. Szylkret oczyszczono acetonem usuwając zarazem zastosowany w poprzedniej konserwacji Mowilith 50, czyli poli(octan winylu). Do klejenia użyto żywicy epoksydowej Fynebond opracowanej przez Normana Tennenta ${ }^{5}$.

Opisane metody konserwacji szylkretu opierają się głównie na metodyce opracowanej dla innych materiałów, takich jak kość słoniowa, bursztyn. Autorzy zalecają dużą ostrożność i delikatność postępowania wobec tego

3 Władysław Ślesiński, Konserwacja zabytków sztuki, t. 3 Rzemiosło artystyczne (Warszawa: Arkady, 1995), 148-149.

4 Janet M. Cronyn, The Elements of Archaeological Conservation (London: Routledge, 2001), 284, 293.

5 Karen Vidler, “Conservation of a tortoiseshell book cover”, Conservation Journal Summer 2005 Issue 50,http://www.vam.ac.uk/content/journals/conservation-journal/issue-50/conservation-of-a-tortoiseshell-book-cover/ 
materiału, z uwzględnieniem różnic zależnych od jego stanu zachowania. Nie wskazują jednak konkretnych środków do zabezpieczania powierzchni szylkretu, konsolidacji rozwarstwionej struktury i jej regeneracji. Jako jedyny sposób na uplastycznienie szylkretu w celu usunięcia deformacji podają działanie na gorąco wodą bądź olejem. Wykonywanie takich zabiegów może być bardzo ryzykowne, a ponadto nie zawsze możliwe do przeprowadzenia (na przykład na markieterii).

Środki, które mogłyby służyć do zabezpieczania zabytkowych obiektów wykonanych z szylkretu, powinny zapewnić utrzymanie równowagi wilgotnościowej zapobiegającej rozwarstwianiu się i kruszeniu, w przy wystąpieniu deformacji - uelastycznienie materiału w stopniu pozwalającym na bezpieczne ich usunięcie. Pewnych rozwiązań można poszukiwać w kosmetologii. W związku z tym zdecydowano się na przebadanie kilku odmian olejów naturalnych, roślinnych i mineralnych, hydrolizowanej keratyny, mocznika oraz Olaplexu - preparatu stosowanego w zaawansowanych zabiegach chemicznych na włosach.

Spośród olejów roślinnych wytypowano ten, który stosowany był w procesie wytwarzania przedmiotów z szylkretu, czyli migdałowy, pozyskiwany przez tłoczenie na zimno nasion drzewa migdałowego (Amygdalus commu$n i s)^{6}$. Ma postać jasnożółtej cieczy o łagodnym, słodkim smaku i zapachu. Jest słabo rozpuszczalny w wodzie i alkoholach. Zawiera 65-68\% kwasu oleinowego, 24-26\% kwasu linolowego, 6-8\% kwasu palmitynowego, 1-2\% kwasu stearynowego, witaminy A, E, D i z grupy B, składniki mineralne. Kwasy linolowy i oleinowy zmiękczają naskórek oraz wzmacniają lipidową barierę ochronną skóry. Witaminy A i E wpływają na jędrność i elastyczność skóry, opóźniają procesy starzenia ${ }^{7}$. Witamina D chroni skórę przed negatywnym działaniem czynników zewnętrznych. Witaminy z grupy B zapobiegają odwodnieniu komórek ${ }^{8}$.

6 Giuseppina Mandalari et al., "Characterization of Polyphenols, Lipids and Dietary Fibre from Almond Skins (Amygdalus communis L.)”, Journal of Food Composition and Analysis 23, no. 2 (2010): 166-174, DOI: 10.1016/j.jfca.2009.08.015.

7 Gerald F. Combs, Jr., The Vitamins. Fundamental Aspect in Nutrition and Health (London: Academic Press, 2012), 93-137, 181-210; Márcio Lorencini et al., "Active Ingredients Against Human Epidermal Aging”, Ageing Research Reviews 15 (2014): 100-115, http://dx.doi. org/10.1016/j.arr.2014.03.002; Marcia Ramos-e-Silva et al., "Anti-Aging Cosmetics: Facts and Controversies”, Clinics in Dermatology 31 (2013): 750-758, http://dx.doi.org/10.1016/j. clindermatol.2013.05.013.

8 Combs, Jr., The Vitamins, 139-178, 261-325. 
Ostatnio bardzo popularny stał się olej arganowy wytwarzany z owoców arganii żelaznej (Argania spinosa) w procesie tłoczenia na zimno ${ }^{9}$. Rozróżnia się dwie jego odmiany: ciemniejszą, stosowaną do celów spożywczych, oraz jaśniejszą, wykorzystywaną w kosmetyce. Olej arganowy rozpuszcza się w tłuszczach. Składa się w 80\% z jedno- i wielonienasyconych kwasów tłuszczowych, zawiera około $45 \%$ kwasu oleinowego i około $35 \%$ kwasu linolowego ${ }^{10}$. Dominują w nim jednonienasycone kwasy tłuszczowe Omega 6 i Omega 9. Zawiera też tokoferole (witamina E, aż 8\%) jako główny antyoksydant, który chroni komórki przed utleniaczami i wzmacnia ścianki naczyń, polifenole o działaniu antyoksydacyjnym i przeciwrodnikowym oraz schotenol, który działa naprawczo i regenerująco. Dzięki obecności fitosteroli olej arganowy wykazuje również działanie przeciwzapalne i łagodzące ${ }^{11}$.

Olej rycynowy otrzymuje się w wyniku tłoczenia na zimno nasion rącznika pospolitego (Ricinus communis) ${ }^{12}$. Jest gęstą cieczą od barwy białej do jasnożółtej, niemal nierozpuszczalną w wodzie. W 80 procentach składa się z kwasu rycynolowego. Dodatkowo zawiera glicerydy kwasów: oleinowego (Omega 9, 7\%), linolowego (Omega 6, 3\%), palmitynowego (2\%), stearynowego $(1 \%)^{13}$. Olej rycynowy jest stosowany przede wszystkim do pielęgnacji włosów i paznokci - wzmacnia je, poprawia ich kondycję i strukturę ${ }^{14}$.

Scharakteryzowane oleje roślinne cechują się zbliżonym do siebie, bardzo bogatym składem. Ich działanie na keratyny zawarte we włosach i paznokciach jest znane i uznane za skuteczne, dlatego należy przypuszczać, że zastosowanie ich na szylkret może przynieść równie satysfakcjonujące efekty. Zawarte w nich witaminy A i E mogą zwiększyć plastyczność materiału, natomiast długoterminowo - zdecydowanie opóźnić i złagodzić procesy

9 Miloudi Hilali et al., "Influence of Origin and Extraction Method on Argan Oil Physico-Chemical Characteristics and Composition”, Journal of Agricultural and Food Chemistry 53 (2005): 2081-2087, DOI 10.1021/jf040290t.

10 Hilali, “Influence”, 2081-2087.

11 Maria L. Manca et al., "Combination of Argan Oil and Phospholipids for the Development of Aneffective Liposome-Like Formulation Able to Improve Skin Hydration and Allantoin Dermal Delivery”, International Journal of Pharmaceutics 505 (2016): 204-211, http://dx.doi. org/10.1016/j.ijpharm.2016.04.008.

12 Jacobs G. Nangbes et al., "Extraction and Characterization of Castor (Ricinus Communis) Seed Oil”, The International Journal of Engineering and Science 2, no. 9 (2013): 105-109, theijes.com/papers/v2-i9/Part.3/P029301050109.pdf, Dostęp 20 lutego 2017.

13 A. K. Yusuf et al., "Extraction and Characterization of Castor Seed Oil from Wild Ricinus Communis Linn", International Journal of Science, Envorinment and Technology 5 (2015): 1392-1395, www.ijset.net/journal/786.pdf, Dostęp 20 lutego 2017.

14 https://esent.pl/pl/p/Olej-Rycynowy-naturalny-100-100-ml/45, Dostęp 20 lutego 2017. 
starzeniowe. Witamina D może zwiększyć odporność szylkretu na działanie światła, witamina B natomiast wspomóc utrzymanie równowagi wilgotnościowej. Kwasy oleinowy (Omega 9) i linolowy (Omega 6) mogą przywrócić elastyczność przesuszonych i zdeformowanych partii obiektów. Te i pozostałe związki obecne w olejach, wnikając w głąb szylkretu, mają szansę zregenerować i częściowo odbudować zerwane łańcuchy białkowe, ulegające degradacji podczas obróbki lub pod wpływem procesów starzeniowych.

Olej bursztynowy wyrabia się jedynie z bursztynu bałtyckiego w procesie podgrzewania żywicy do temperatury $200^{\circ} \mathrm{C}$. Ciecz ma barwę złocistą i silnie żywiczny aromat. W kosmetyce olej bursztynowy, jako nośnik tlenu i jonów ujemnych, jest wykorzystywany do odbudowy tkanki skórnej. Ma również właściwości dezynfekcyjne i antyseptyczne.

Od opisanej grupy związków różni się keratyna hydrolizowana, produkowana metodą kontrolowanej hydrolizy enzymatycznej wełny owczej. Jest jednorodną, klarowną cieczą o barwie bursztynowej. Nierozpuszczalna w tłuszczach, rozpuszcza się w wodzie i alkoholach. Jej substancje aktywne stanowi grupa aminokwasów zbliżona do składu ludzkich włosów: cystyna - odpowiadająca za prawidłową wewnętrzną strukturę włosa (9-10\%), glicyna, kwas glutaminowy, seryna, prolina, kwas asparaginowy, arginina, walina, alanina, treonina, lizyna, histydyna ${ }^{15}$. Keratyna w formie hydrolizatu wnika w strukturę włosa i wiąże się z łańcuchami białkowymi wbudowując się w uszkodzone miejsca, co prowadzi do zwiększenia wytrzymałości mechanicznej. Na powierzchni włosów wytwarza koloidy zabezpieczające przed szkodliwym działaniem czynników zewnętrznych. Dodatkowo przywraca równowagę wilgotnościową włosów. Keratyna zastosowana do pielęgnacji paznokci odbudowuje strukturę płytki, wzmacnia ją i utwardza oraz zapobiega łamaniu ${ }^{16}$.

Z kolei syntetyczny mocznik jest pozyskiwany w procesie syntezy amoniaku w formie białego, krystalicznego proszku. Jest rozpuszczalny w wodzie i alkoholach, bardzo szybko ulega hydrolizie. Środek ten ma bardzo szerokie zastosowanie w produktach kosmetycznych. Podobnie jak gliceryna i kwas hialuronowy ma zdolność wiązania wody w warstwie rogowej naskórka ${ }^{17}$. Właściwości mocznika w dużej mierze zależą od jego stężenia. W stężeniu 2-procentowym aktywuje podziały komórek warstwy ziarnistej skóry, działa

15 Clarence R. Robbins, Chemical and Physical Behavior of Human Hair (Berlin, Heidelberg: Springer-Verlag, 2012), 105-120.

16 https://esent.pl/pl/p/Keratyna-hydrolizowana-30-ml/25, Dostęp 15 maja 2016.

17 Nanotechnologia, kosmetyki, chemia supramolekularna, red. Grzegorz Schroeder (Kostrzyń: Wydawnictwo Cursiva, 2010), 123-140. 
silnie regeneracyjnie, na poziomie $5-10 \%$ pochłania wodę i ułatwia jej wiązanie przez keratynę. W roztworach o stężeniu ponad 10-procentowym wpływa na reces rogowacenia naskórka i działa łagodnie złuszczająco, ale już powyżej 40-50\% powoduje rozrywanie wiązań w keratynie, co prowadzi do jej denaturacji, a następnie solubilizacji ${ }^{18}$. Mocznik nieznacznie zwiększając wilgotność szylkretu może przywrócić mu plastyczność, ułatwić usunięcie zniekształceń oraz pomóc w utrzymaniu równowagi wilgotnościowej.

Olaplex jest preparatem fryzjerskim stosowanym równolegle z zabiegami chemicznymi: ta dwuetapowa kuracja ma na celu przywrócenie prawidłowej struktury keratyny przez łączenie zerwanych wiązań disiarczkowych i budowę nowych. Jego aktywnym składnikiem jest bis-aminopropyl diglikolu dimaleinowego, czyli kompleks łańcuchów węglowych, wodorowych, azotowych oraz tlenowych ${ }^{19}$. Olaplex uwzględniono w badaniach jako produkt mogący wpłynąć na regenerację zdezintegrowanego szylkretu.

Jednym ze środków popularnie stosowanych w konserwacji jest Paraloid B-72, kopolimer metakrylanu etylu i akrylanu metylu. Rozpuszcza się w wybranych węglowodorach aromatycznych, estrach, ketononach, eterach, dając roztwory o niskiej lepkości. Mięknie w temperaturze $70-75^{\circ} \mathrm{C}$, uplastycznia się w $145-150^{\circ} \mathrm{C}$, a jej rozkład termiczny następuje w $250-300^{\circ} \mathrm{C}$. Na tle innych żywic termoplastycznych Paraloid B-72 wyróżnia się bardzo wysoką odpornością na działanie promieni UV - nie żółknie i jest odporny na sieciowanie. Stosuje się go do otrzymania werniksów ochronnych, ale również do wypełnienia spękań i podklejania łusek ${ }^{20}$, co mogłoby być głównym kierunkiem zastosowania Paraloidu B-72 w konserwacji szylkretu. Poza tym daje możliwość utworzenia powłoki zabezpieczającej przed promieniami słonecznymi.

\section{Metodyka badań}

Do badań przygotowano dwa typy próbek: fragmenty szylkretu w dobrym stanie zachowania, mające nieliczne zarysowania na powierzchni i miejscowe zmatowienia, oraz łuski żółwia wodnego Trachemys scripta troostii naturalnie złuszczające się z karapaksu.

18 Nanotechnologia, 133.

19 Informacje zawarte na stronie producenta. http://www.olaplex.com/; http://www.labmuffin.com/2015/04/how-does-olaplex-hair-treatment-work, Dostęp 15 maja 2016.

20 Jerzy Ciabach, „Właściwości i zastosowanie Paraloidu B-72”, Ochrona Zabytków 35 (1982): 111-112. 
Próbki suszono w temperaturze $60^{\circ} \mathrm{C}$ przez 48 godzin. Po tym działaniu znacznie spadła ich elastyczność - dotyczy to zwłaszcza łusek żółwia. Po ostudzeniu próbki pokryto obustronnie wybranymi produktami nanoszonymi miękkim pędzlem, to jest: olejem ze słodkich migdałów (nierafinowany, tłoczony na zimno, 100-procentowy), olejem arganowym (nierafinowany, tłoczony na zimno, 100-procentowy), olejem rycynowym (nierafinowany, 100-procentowy), olejem bursztynowym (100-procentowy), keratyną hydrolizowaną (100-procentowa), mocznikiem (5-procentowy wodny roztwór), Paraloidem B-72 (10-procentowy roztwór w ksylenie). Produkt Olaplex zastosowano według zaleceń producenta. Próbki pokryto 10-procentowym roztworem wodnym Olaplex No. 1 i pozostawiono na 5 minut. Następnie powierzchnię przetarto wilgotną ściereczką - co miało zastąpić zalecane spłukanie - i naniesiono 100-procentowy roztwór Olaplex No. 2, którego nadmiar usunięto po upływie 10 minut. Próbki pozostawiono pod przykryciem na 72 godziny w celu nasycenia ich preparatami, a następnie powtórzono zabieg.

Po upływie kolejnych 72 godzin próbki podzielono na dwie grupy. Pierwszą grupę próbek, po usunięciu nadmiaru zastosowanych preparatów z ich powierzchni, umieszczono w komorze klimatycznej Vötsch VC 4033 i poddano działaniu zmiennych warunków przez sto cykli. Jeden cykl obejmuje przebywanie materiału przez dwie godziny w temperaturze $40^{\circ} \mathrm{C}$ i 0 -procentowej wilgotności względnej oraz przez kolejne dwie godziny w tej samej temperaturze i wilgotności względnej podniesionej do $100 \%$.

Materiał pozyskany ze skorupy żółwia poddano ocenie wizualnej i organoleptycznej, porównując próbki z obu grup w celu określenia zmian elastyczności oraz przemian powierzchniowych. Kolejne obserwacje przeprowadzono za pomocą mikroskopu stereoskopowego. Powierzchnię łusek oraz szylkretu analizowano pod kątem zmian, jakie zaszły po naniesieniu preparatów oraz po stu cyklach w komorze klimatycznej. Następnie wykonano przekroje próbek szylkretu: nasyconych oraz poddanych wpływom zmiennych warunków wilgotnościowych. Zbadano je pod skaningowym mikroskopem elektronowym Quanta 3D FEG ${ }^{21}$, oceniając stan powierzchni i zmiany będące efektem przeprowadzonych działań.

W celu ustalenia zmian powierzchniowych na próbkach z szylkretu oraz łuskach żółwia wykonano oznaczenie chropowatości ich powierzchni. Dla określenia tej wartości przeprowadzono obrazowanie z wykorzystaniem mi-

21 Badania wykonano w Pracowni Analiz Instrumentalnych na Wydziale Chemii UMK w Toruniu, przeprowadziła je Anna Kmieciak. 
kroskopu sił atomowych. Analizę próbek szylkretu nasyconego oraz nasyconego i poddanego działaniu zmiennych warunków klimatycznych wykonano mikroskopem sił atomowych ze skanującą sondą SPM produkcji Veeco (Digital Instrument). W skład systemu wchodzą: kontroler NanoScope IIIa i Quadrex, mikroskop MultiMode, skaner typu E z maksymalnym obszarem skanowania 10x10x2,5 [um $]^{22}$. Natomiast do analizy łusek żółwia użyto BioScope II firmy Veeco ${ }^{23}$.

Chropowatość powierzchni oznacza rozpoznawalne optycznie lub wyczuwalne mechanicznie nierówności rzeczywistej powierzchni przedmiotu o stosunkowo małych odstępach między wierzchołkami. Jej wielkość zależy od rodzaju materiału oraz jego obróbki ${ }^{24}$. W analizie porównawczej wykorzystano następujące parametry chropowatości ${ }^{25}$ :

Rq - stanowiącą średnią arytmetyczną wartość bezwzględnych odchyleń profilu od linii średniej w przedziale odcinka elementarnego l:

$$
R_{a}\left(l_{c}\right)=\frac{1}{l} \int_{0}^{1}|y(x)| d x
$$

Parametr ten może być też wyrażony jako stosunek całkowitego pola powierzchni próbki do odpowiadającej jej powierzchni płaskiej o wymiarach $\mathbf{L}_{\mathrm{x}} \mathrm{i} \mathbf{L}_{\mathrm{y}}$ :

$$
R_{a}=\frac{1}{L_{x} L_{y}} \int_{0}^{L_{x}} \int_{0}^{L_{y}}|f(x, y)| d x d y
$$

kwadratową odchylenia profilu chropowatości $\left(\mathrm{R}_{\mathrm{q}}\right)$ :

$$
\mathbf{R}_{\mathbf{q}}=\left[\frac{\sum_{\mathrm{i}}\left(\mathbf{Z}_{\mathrm{i}}-\mathbf{Z}_{\mathrm{avg}}\right)^{2}}{\mathbf{N}}\right]^{0,5}
$$

$\mathrm{Z}_{\mathrm{i}}$ - odległości tego punktu od średniego poziomu $\mathrm{Z}_{\mathrm{avg}}$.

22 Badania wykonano w Pracowni Analiz Instrumentalnych na Wydziale Chemii UMK w Toruniu, przeprowadziła je dr Grażyna Szczepańska.

23 Badania wykonano w Zakładzie Biofizyki i Fizyki Medycznej na Wydziale Fizyki, Astronomii i Informatyki Stosowanej UMK w Toruniu, przeprowadził je dr Janusz Strzelecki.

24 Halina Karczmarek et al., „Badania polimerów z wykorzystaniem metody mikroskopii sił atomowych", Polimery 47 (2002): 775-783, Dostęp 20 lutego 2017.

25 Karczmarek et al., „Badania”, 775-783. 


\section{Ocena wizualna i organoleptyczna}

Ocenę organoleptyczną zmian materiału pozyskanego ze skorupy żółwia po poddaniu go oddziaływaniu zmiennych warunków klimatycznych przedstawiono w tabeli 1.

Tabela 1. Ocena wizualna i organoleptyczna zmian na łuskach żółwia wodnego po nasyceniu preparatami oraz po oddziaływaniu zmiennych warunków klimatycznych

\begin{tabular}{|c|c|c|c|}
\hline Lp. & Preparat & Zmiany po nasyceniu & $\begin{array}{l}\text { Zmiany po oddziaływaniu } \\
\text { zmiennych warunków } \\
\text { klimatycznych }\end{array}$ \\
\hline 1 & 2 & 3 & 4 \\
\hline 1 & - & $\begin{array}{l}\text { łuska elastyczna, nie odkształca } \\
\text { się przy próbie zgięcia, przy dużym } \\
\text { nacisku ulega zniszczeniu }\end{array}$ & $\begin{array}{l}\text { spadek elastyczności, przy nacisku } \\
\text { odkształca się, następnie ulega } \\
\text { zniszczeniu }\end{array}$ \\
\hline 2 & $\begin{array}{l}\text { olej } \\
\text { migdałowy }\end{array}$ & $\begin{array}{l}\text { wzrost elastyczności, nie odkształca } \\
\text { się, ale przy dużym nacisku łamie się } \\
\text { i pęka }\end{array}$ & spadek elastyczności \\
\hline 3 & olej arganowy & $\begin{array}{l}\text { bardzo duży wzrost elastyczności } \\
\text { (największy z uzyskanych pod } \\
\text { wpływem badanych olejów), przy } \\
\text { bardzo dużym nacisku minimalne } \\
\text { odkształcenie, nie ulega zniszczeniu, } \\
\text { wzrost transparentności }\end{array}$ & $\begin{array}{l}\text { niewielkie zmatowienie, } \\
\text { przy bardzo dużym nacisku } \\
\text { odkształcenie, łamie się, ale nie } \\
\text { pęka }\end{array}$ \\
\hline 4 & olej rycynowy & $\begin{array}{l}\text { wzrost elastyczności, przy nacisku } \\
\text { łamie się, ale nie pęka }\end{array}$ & $\begin{array}{l}\text { wzrost transparentności, przy } \\
\text { nacisku łamie się, nie pęka }\end{array}$ \\
\hline 5 & $\begin{array}{l}\text { olej } \\
\text { bursztynowy }\end{array}$ & $\begin{array}{l}\text { spadek elastyczności, przy nacisku } \\
\text { rozwarstwia się i pęka, zmiana } \\
\text { zabarwienia na jasnobrązowe }\end{array}$ & $\begin{array}{l}\text { bardzo duży spadek elastyczności, } \\
\text { próbka bardzo twarda, pęka przy } \\
\text { nacisku, zmiany na powierzchni } \\
\text { - rozwarstwienie w formie } \\
\text { pęcherzyków }\end{array}$ \\
\hline 6 & $\begin{array}{l}\text { keratyna } \\
\text { hydrolizowana }\end{array}$ & $\begin{array}{l}\text { spadek elastyczności, przy nacisku } \\
\text { tamie się i odkształca, ale nie pęka }\end{array}$ & $\begin{array}{l}\text { zmatowienie, zabielenie, } \\
\text { łuszczenie, przy nacisku łamie się } \\
\text { i pęka }\end{array}$ \\
\hline
\end{tabular}


Cd. tab. 1

\begin{tabular}{|c|l|l|l|}
\hline 1 & \multicolumn{1}{|c|}{$\mathbf{2}$} & \multicolumn{1}{|c|}{3} & \multicolumn{1}{|c|}{4} \\
\hline 7 & mocznik & $\begin{array}{l}\text { spadek elastyczności, przy nacisku } \\
\text { ulega zniszczeniu }\end{array}$ & $\begin{array}{l}\text { bardzo duży spadek } \\
\text { elastyczności, pogłębienie zmian } \\
\text { powierzchniowych, przy nacisku } \\
\text { kruszy się }\end{array}$ \\
\hline 8 & Olaplex & $\begin{array}{l}\text { bardzo duży wzrost elastyczności, przy } \\
\text { nacisku łamie się, ale nie odkształca, } \\
\text { nie pęka, lekkie zmatowienie } \\
\text { powierzchni }\end{array}$ & $\begin{array}{l}\text { nieznaczny spadek elastyczności, } \\
\text { pęka przy dużym nacisku, } \\
\text { pogłębienie zmatowienia } \\
\text { powierzchni }\end{array}$ \\
\hline 9 & Paraloid B-72 & $\begin{array}{l}\text { bardzo duży spadek elastyczności, } \\
\text { przy nacisku pęka }\end{array}$ & $\begin{array}{l}\text { łuszczenie, zmatowienie, łamie się, } \\
\text { odkształca i pęka }\end{array}$ \\
\hline
\end{tabular}

Największy wzrost elastyczności łusek żółwia odnotowano po zastosowaniu preparatu Olaplex, którego działanie utrzymuje się mimo wpływu zmiennych warunków wilgotnościowych. Wszystkie naturalne oleje roślinne spowodowały wzrost elastyczności, który w niewielkim stopniu obniżył się po stu cyklach przechowywania w komorze klimatycznej. Pozostałe preparaty, tj. olej bursztynowy, mocznik, hydrolizowana keratyna, Paraloid B-72, spowodowały zdecydowany spadek elastyczności, pogłębiający się po przeprowadzeniu badań. Zmian powierzchniowych takich jak matowienie i łuszczenie nie zaobserwowano tylko przy udziale olejów migdałowego i rycynowego. Nieznaczne zmiany w wyglądzie łuski zaszły po zastosowaniu oleju arganowego.

\section{Analiza mikroskopowa}

Obserwacje mikroskopowe próbek szylkretu oraz łusek nasyconych i poddanych działaniu zmiennych warunków klimatycznych zamieszczono w tabelach 2 i 3. 


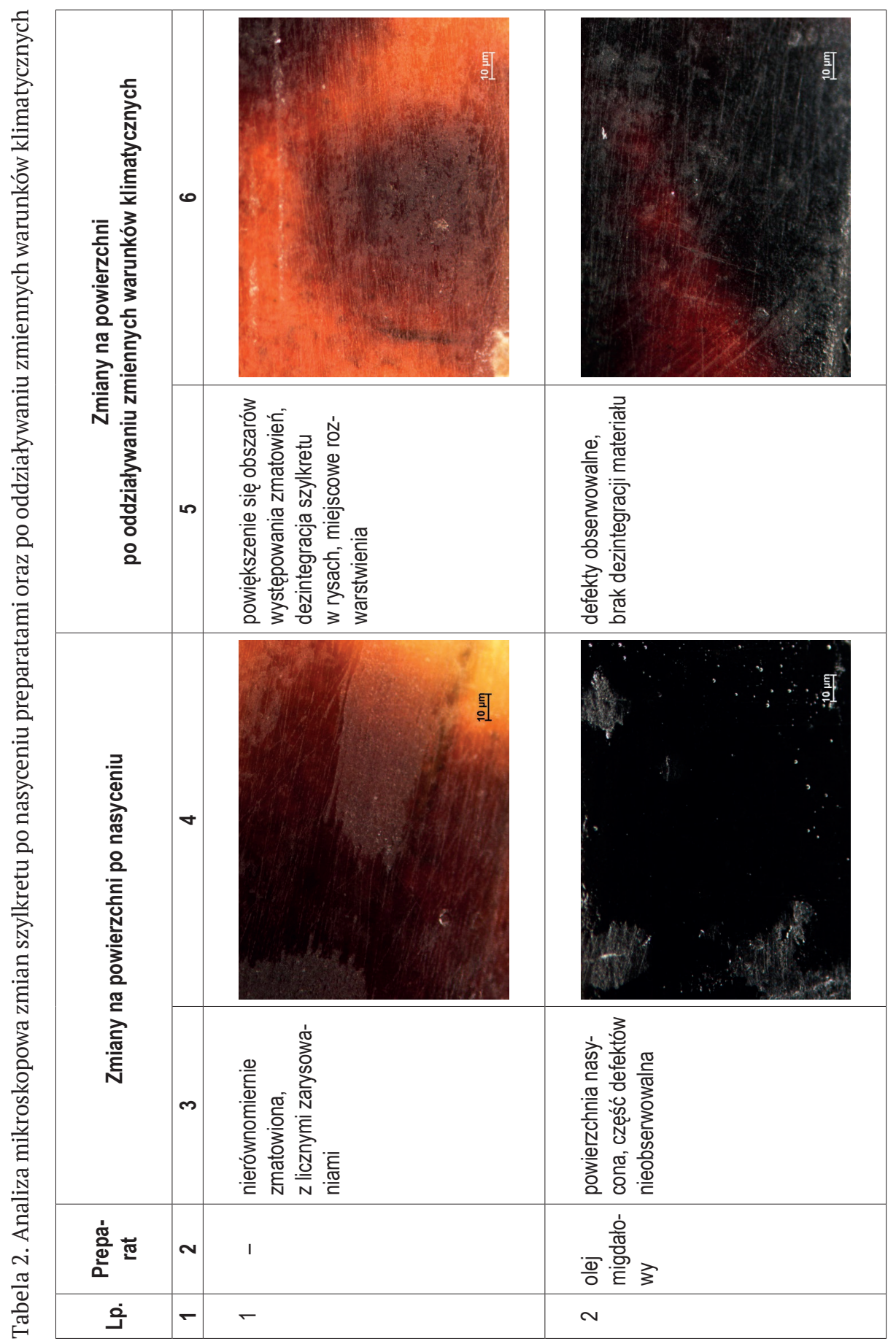




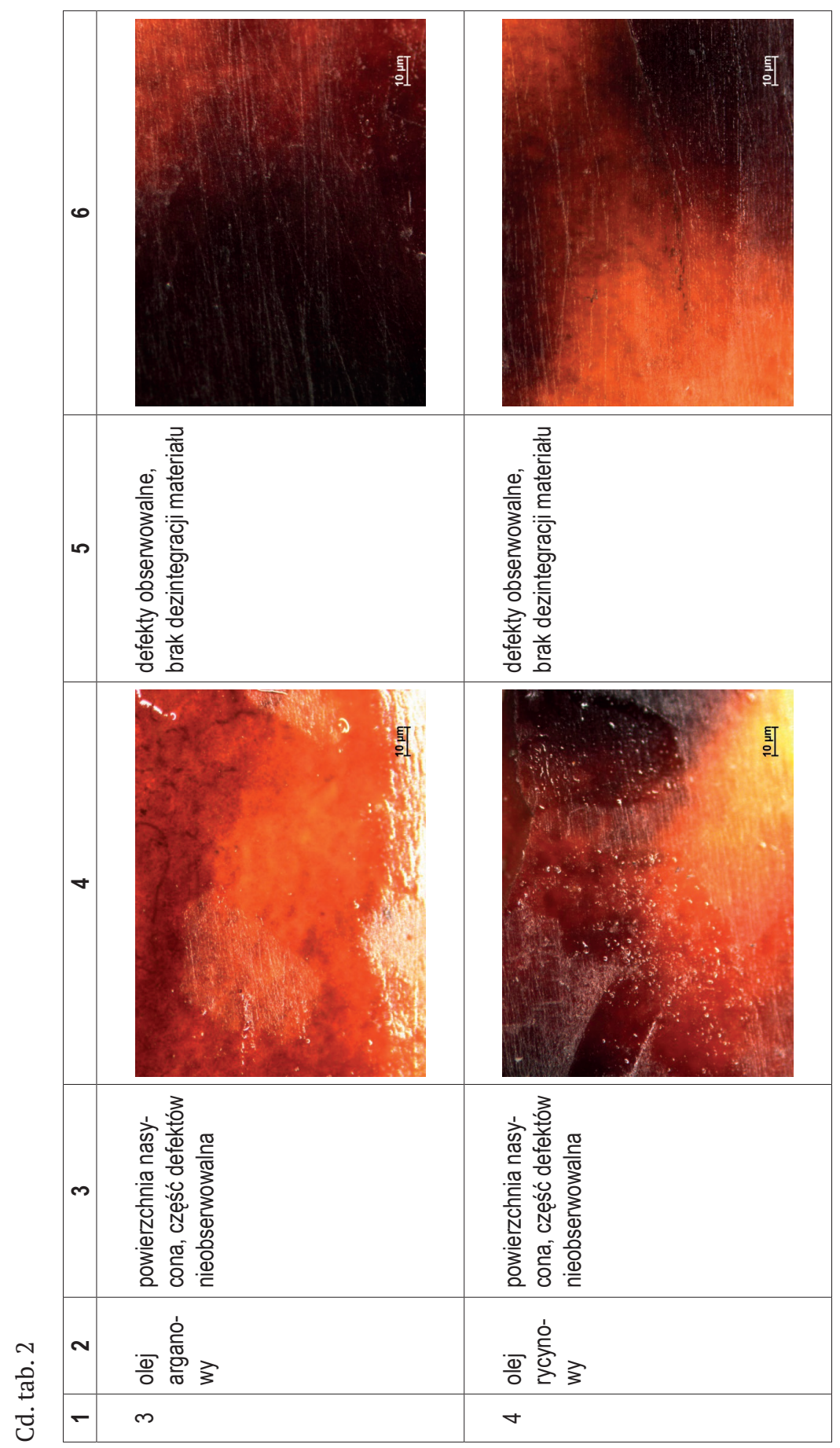




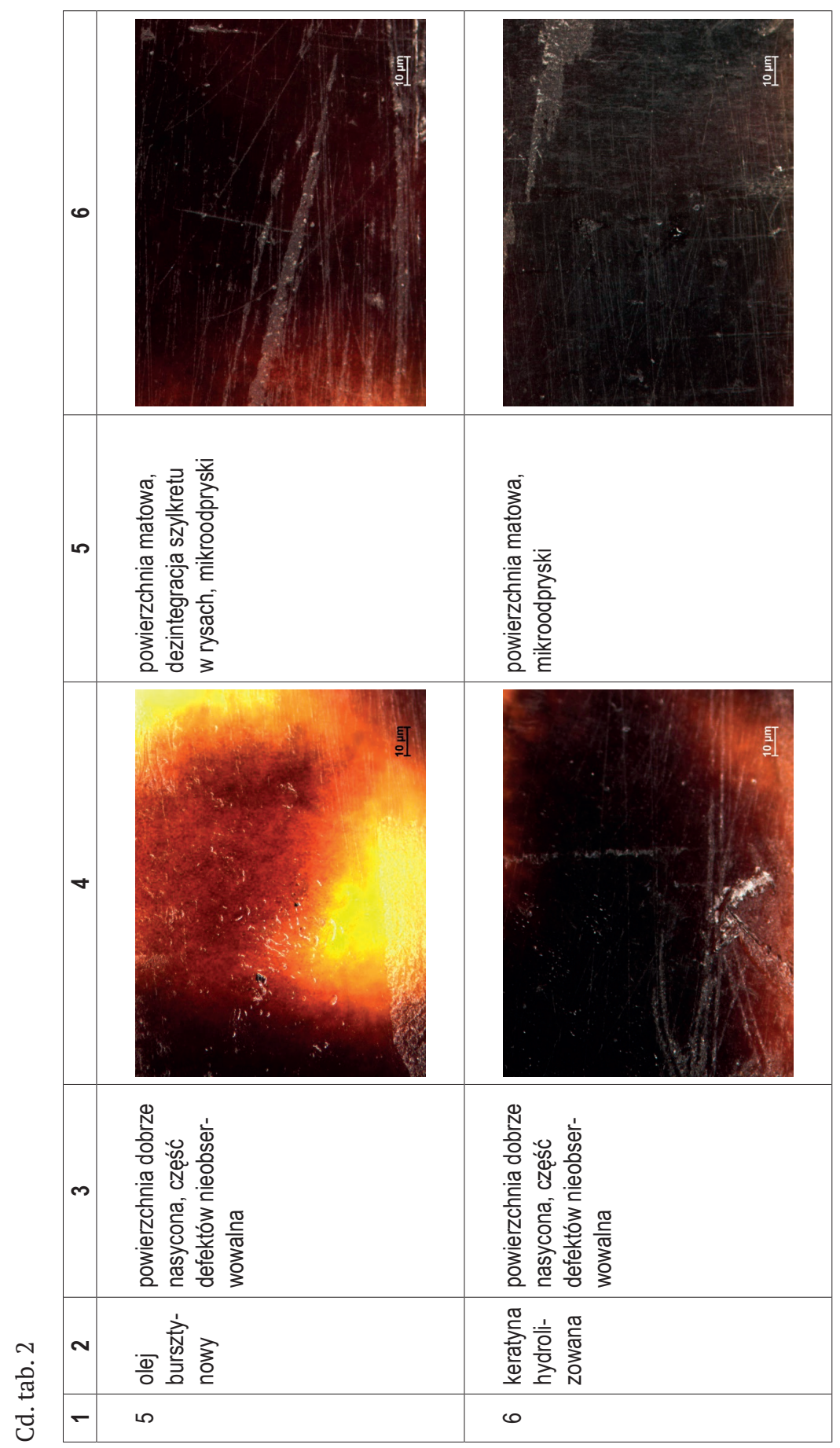




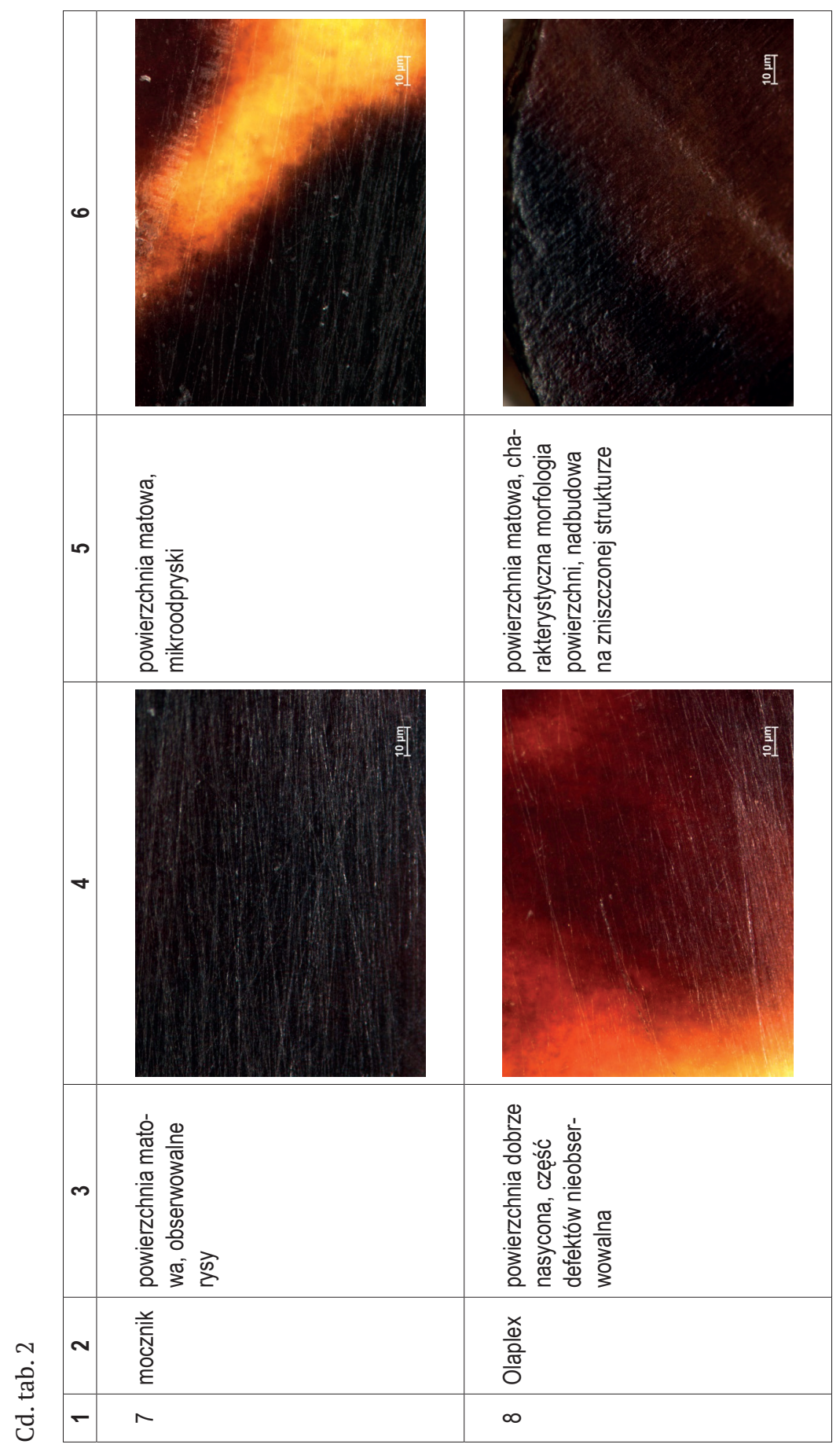




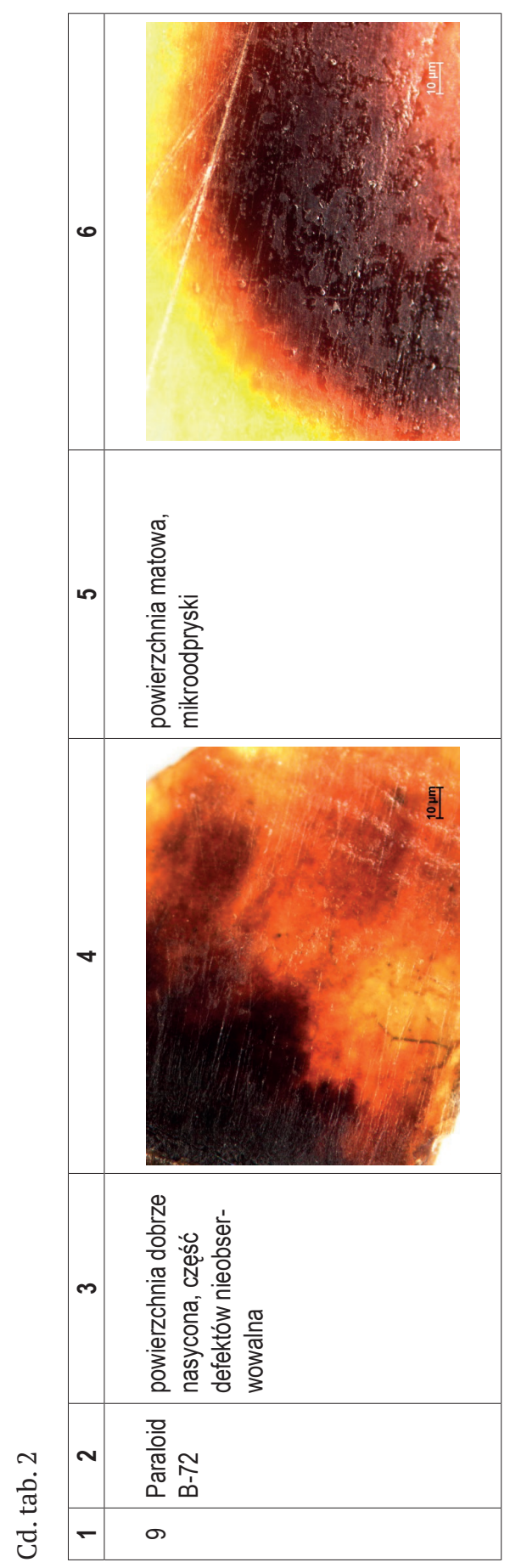




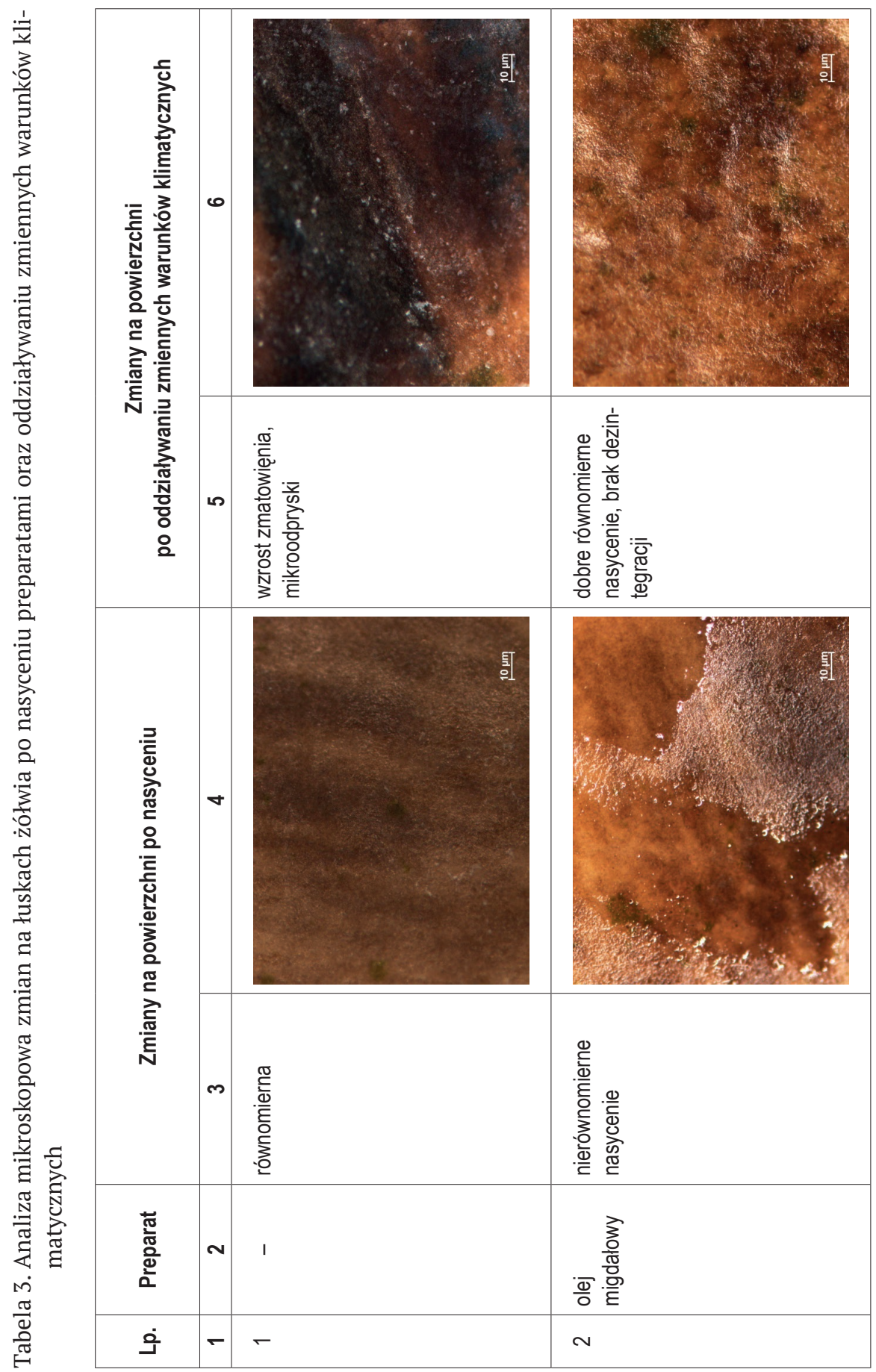




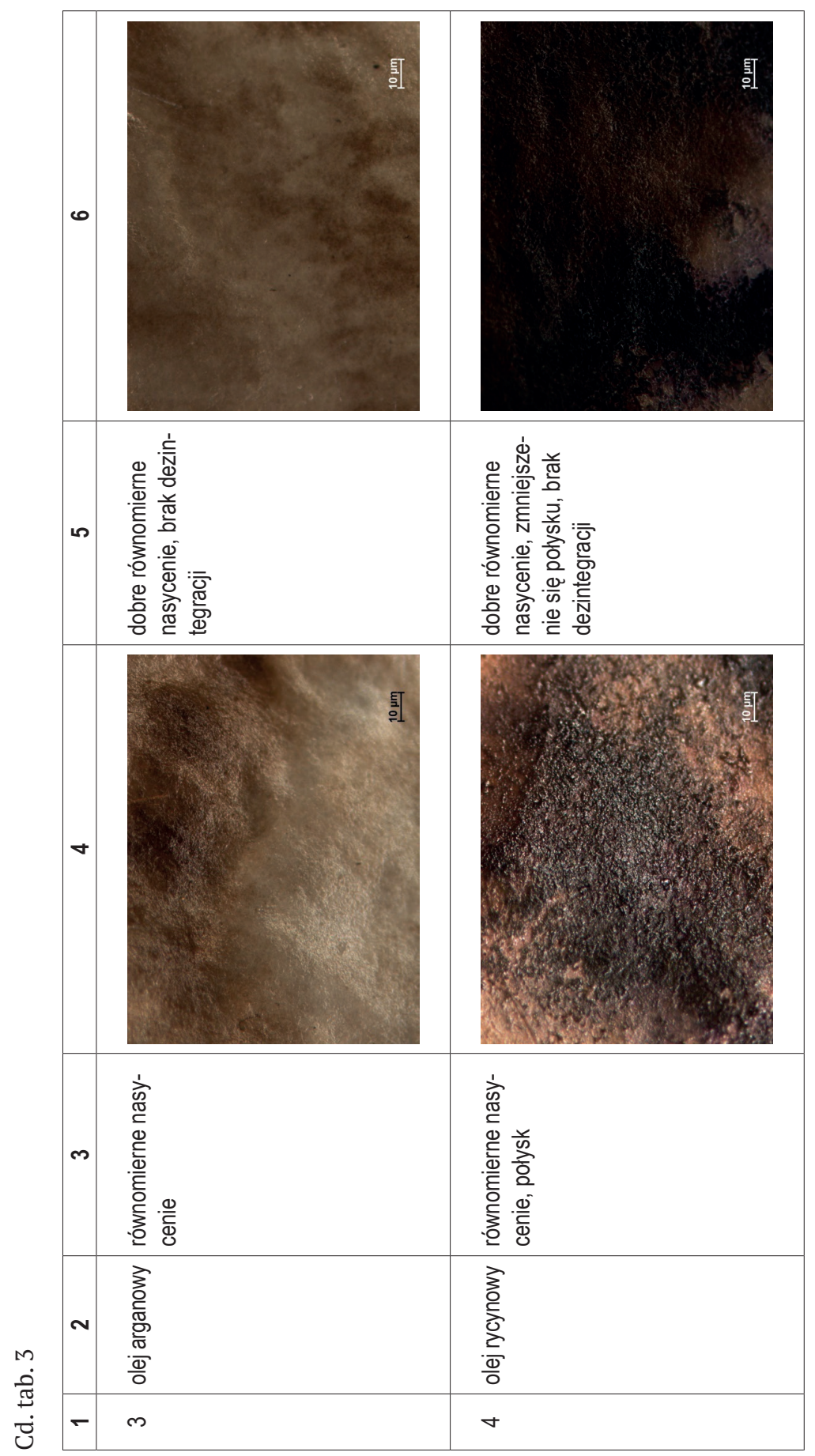




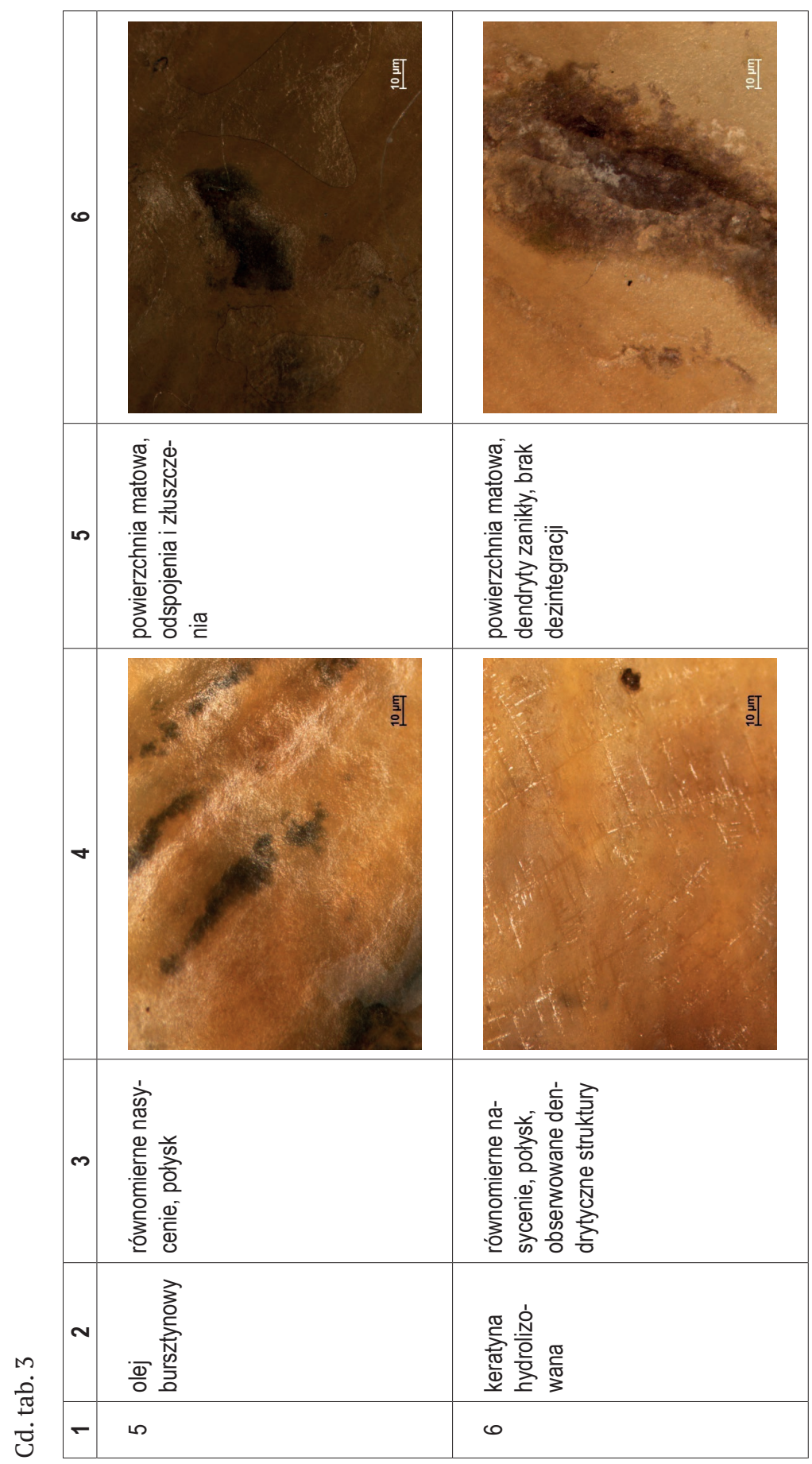




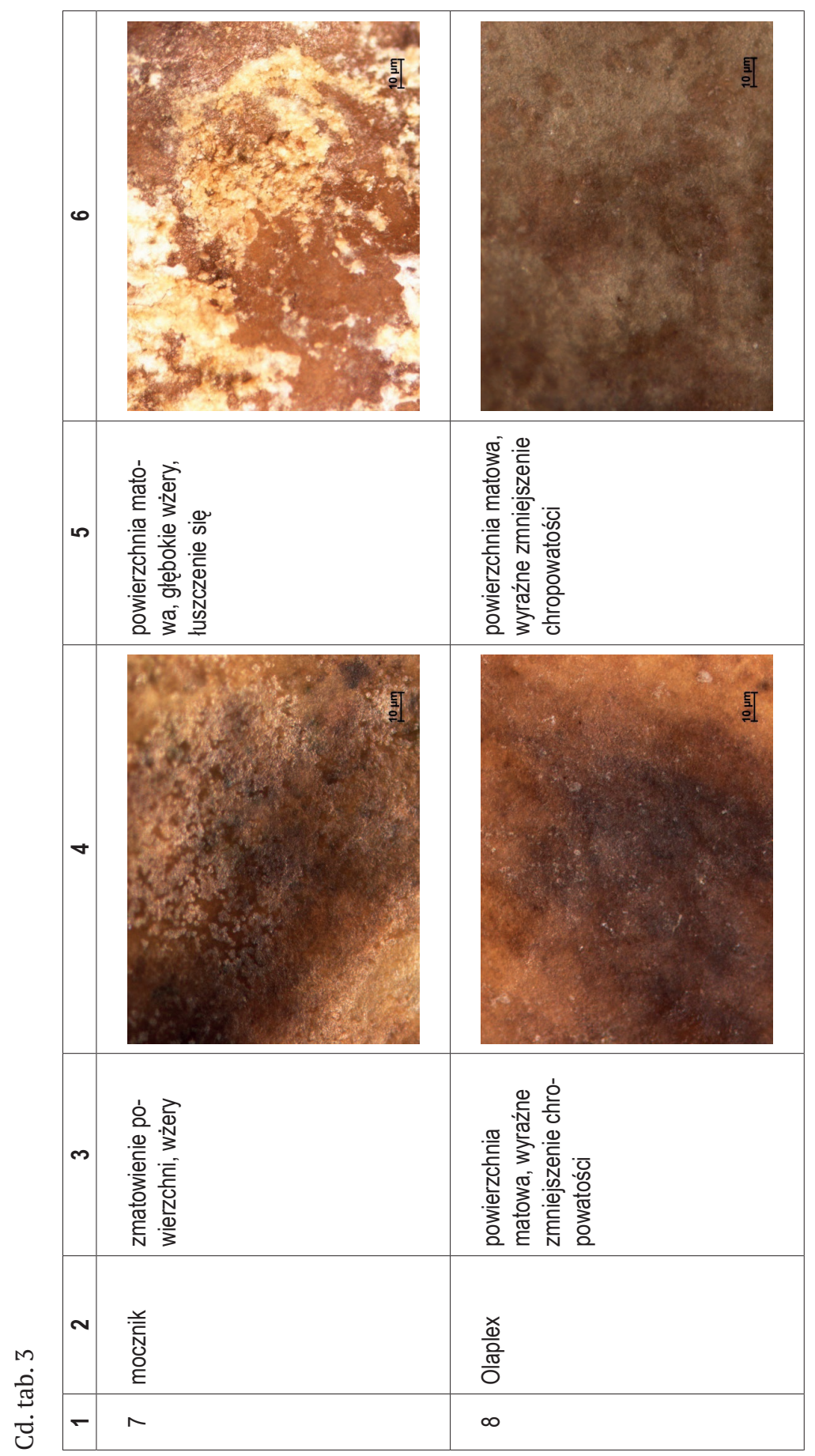




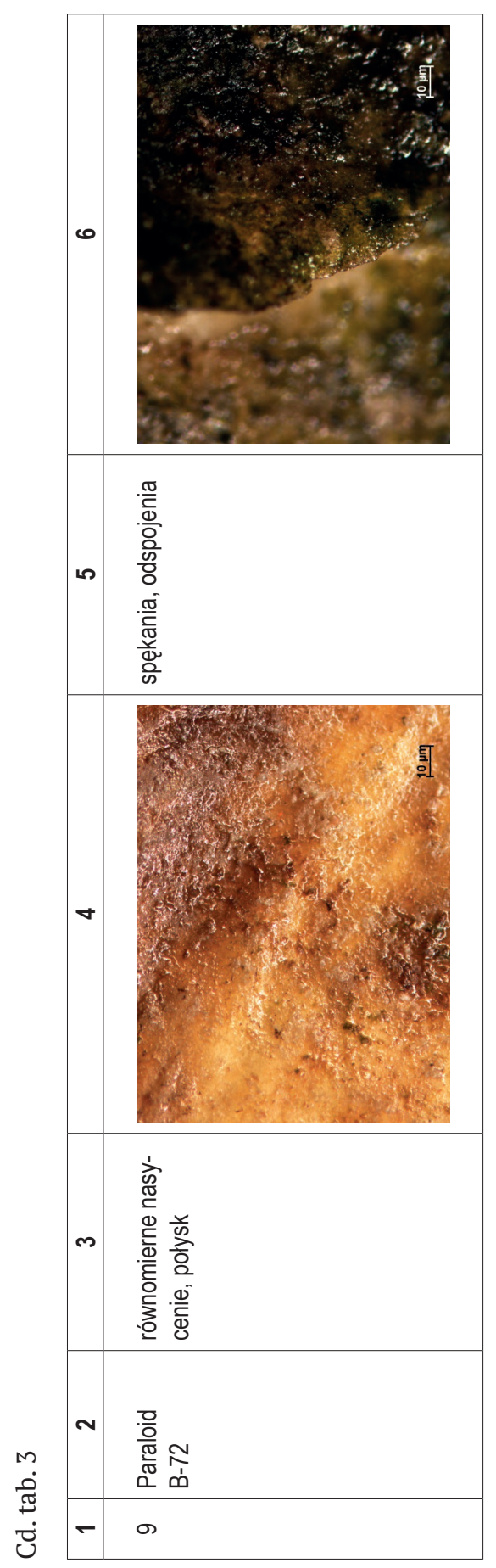


Naturalne oleje roślinne dobrze nasycają powierzchnię szylkretu, co wyraźnie poprawiło jej kondycję, między innymi wpływając na zmniejszenie obserwowalności defektów. Początki dezintegracji powierzchni odnotowano na próbkach zabezpieczonych olejem bursztynowym, mocznikiem oraz lakierem na bazie Paraloidu B-72. Na łuskach żółwia najlepszy efekt wygładzenia powierzchni zaobserwowano po zastosowaniu olejów: migdałowego, argantowego, rycynowego i bursztynowego, keratyny hydrolizowanej oraz preparatu Olaplex. Obniżenie elastyczności, objawiające się łuszczeniem i/ lub pękaniem, wykazał materiał nasycony mocznikiem oraz Paraloidem B-72. Najbardziej szkodliwie oddziałał na keratynę mocznik, który doprowadził do powstania głębokich wżerów.

Na mikrofotografiach próbek impregnowanych preparatem Olaplex widoczna jest ich charakterystyczna struktura. Morfologia powierzchni wskazuje na nadbudowę na badanym materiale aktywnych składników preparatu. Powierzchnia uległa zmatowieniu, zmniejszyła się jej chropowatość, a rysy i pęknięcia zostały wypełnione.

\section{Analiza techniką skaningowej mikroskopii elektronowej}

Ocenę zmian na przekrojach próbek szylkretu po naniesieniu preparatów oraz po działaniu zmiennych warunków klimatycznych analizowanych przy użyciu mikroskopu elektronowego Quanta 3D FEG zamieszczono w tabeli 4. 


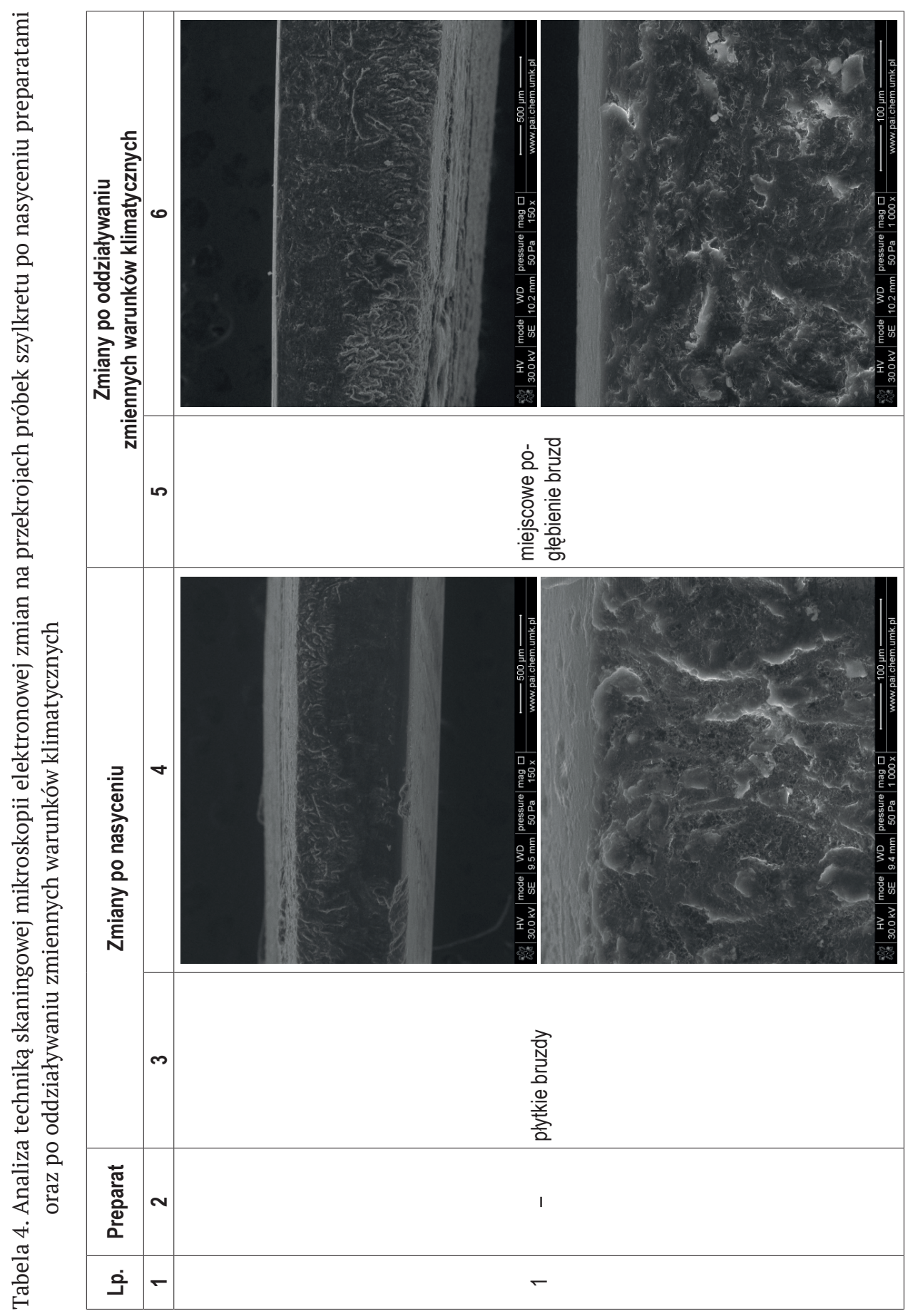




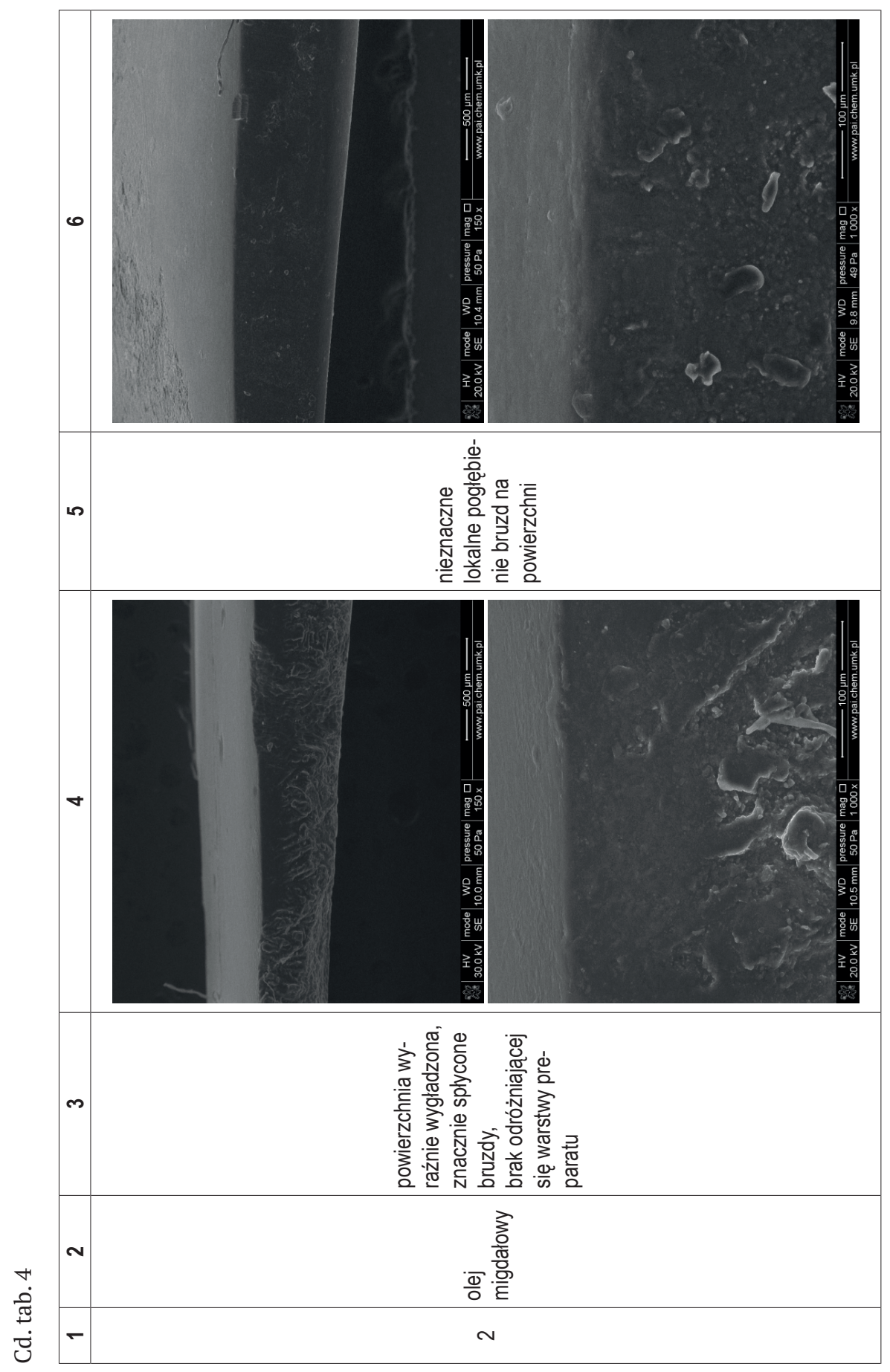




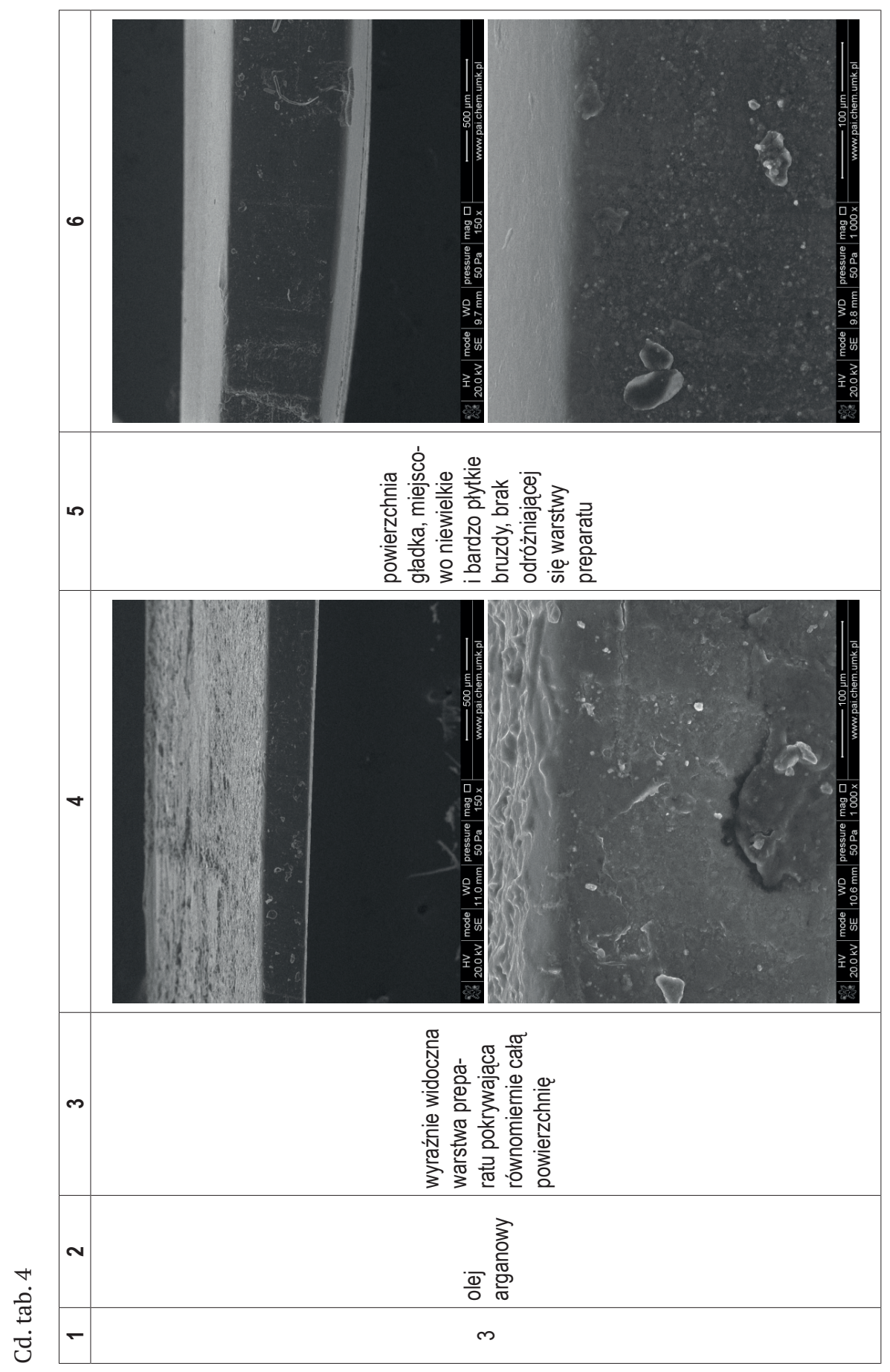




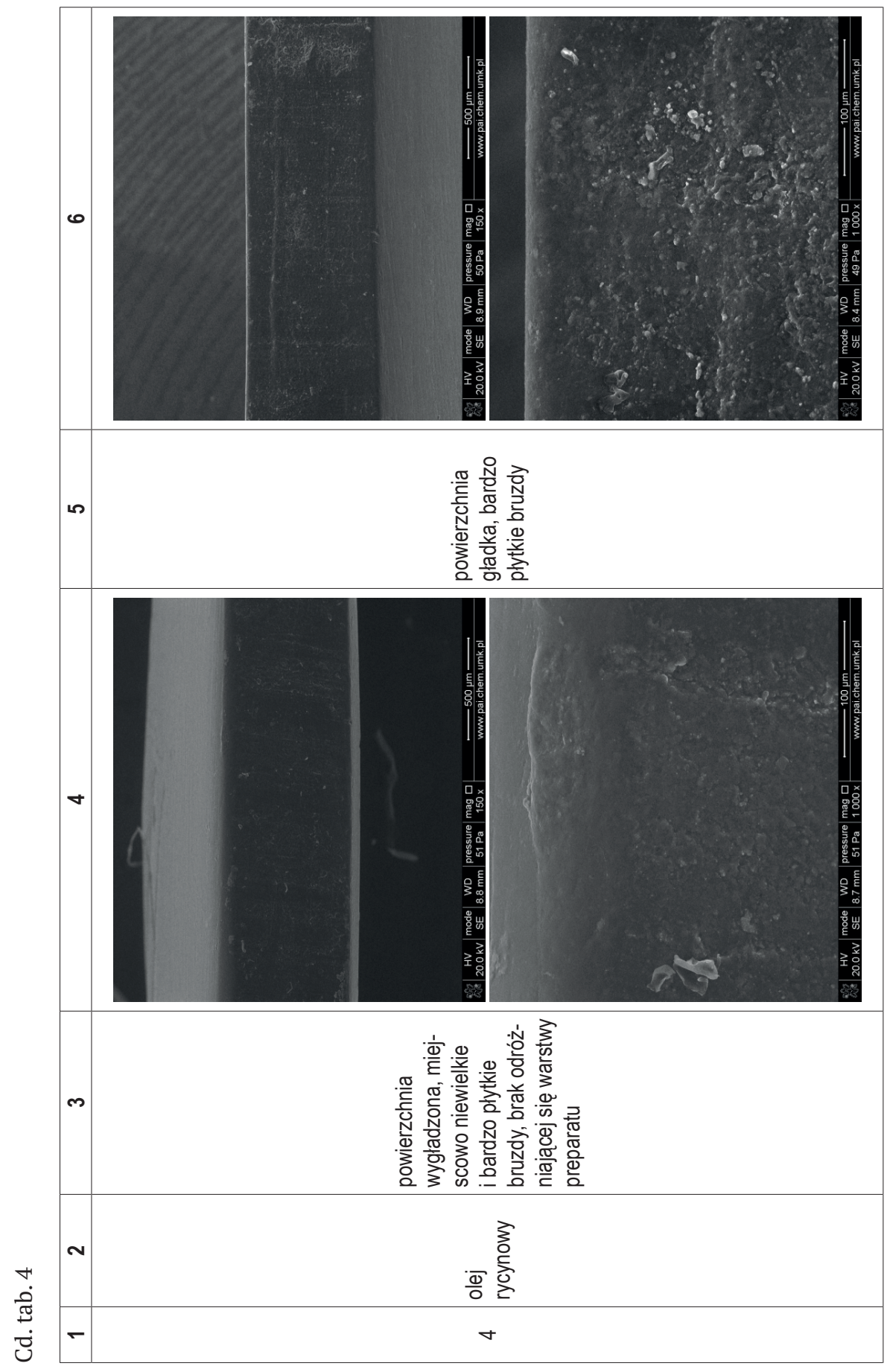




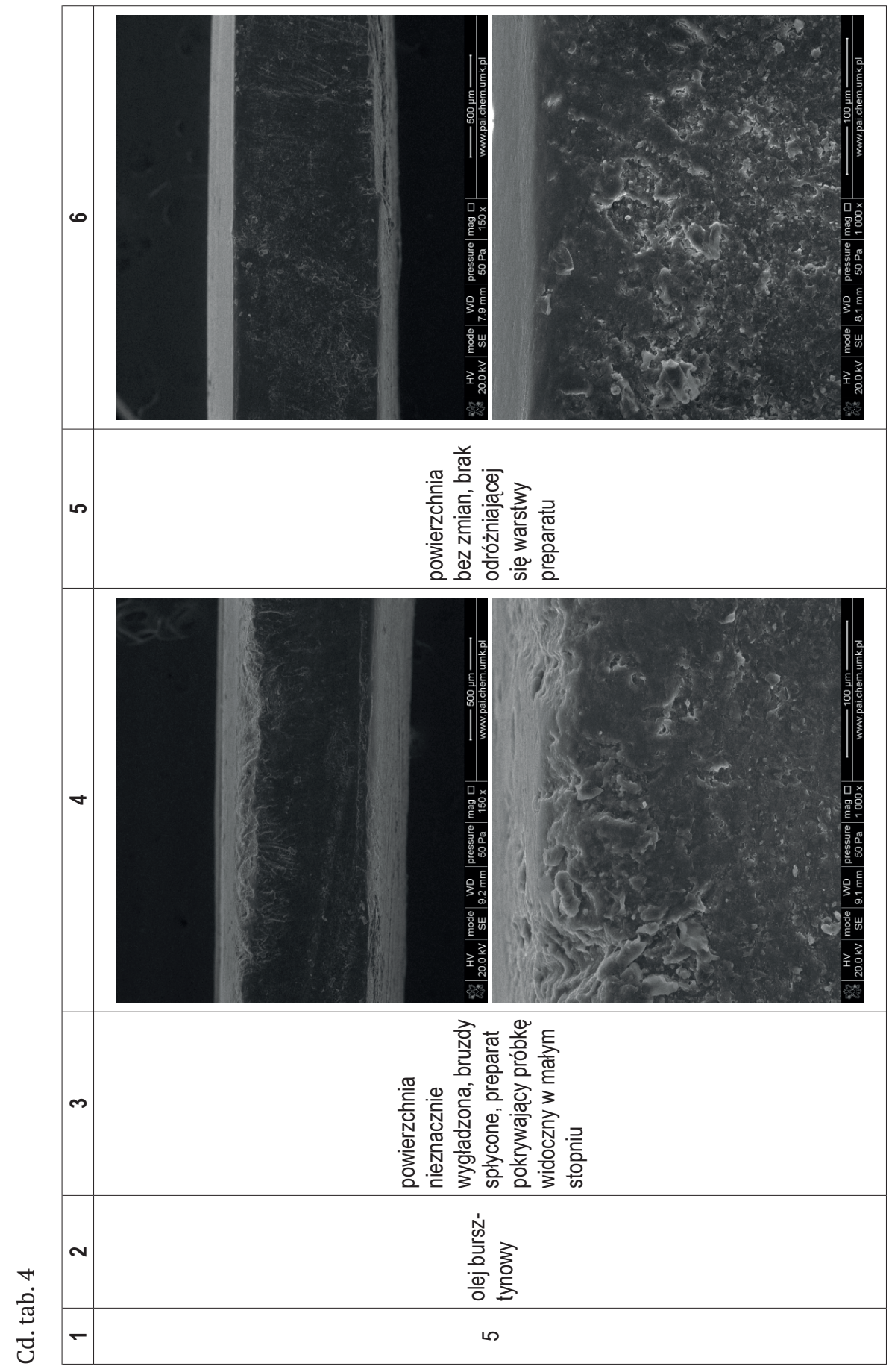




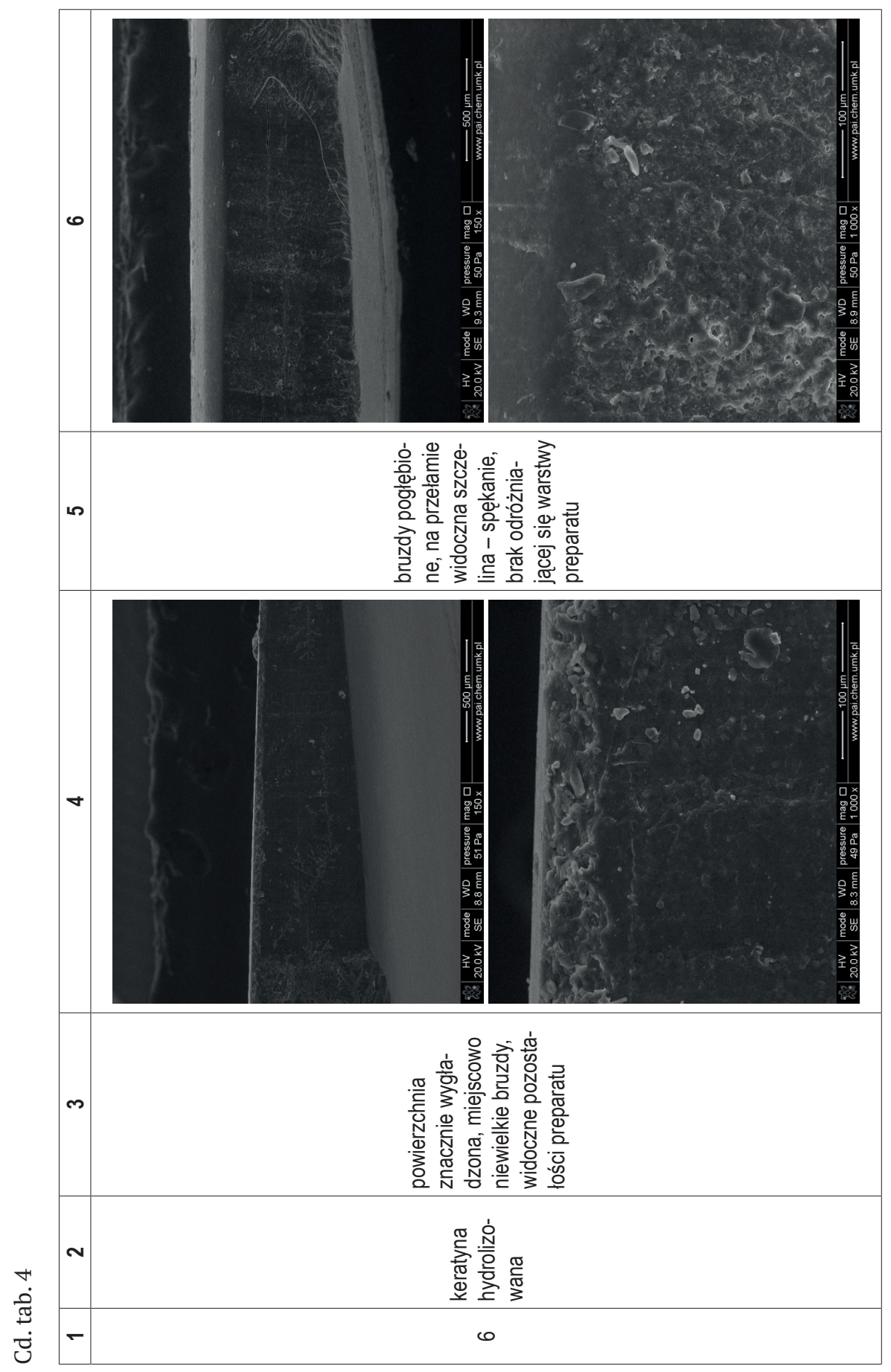




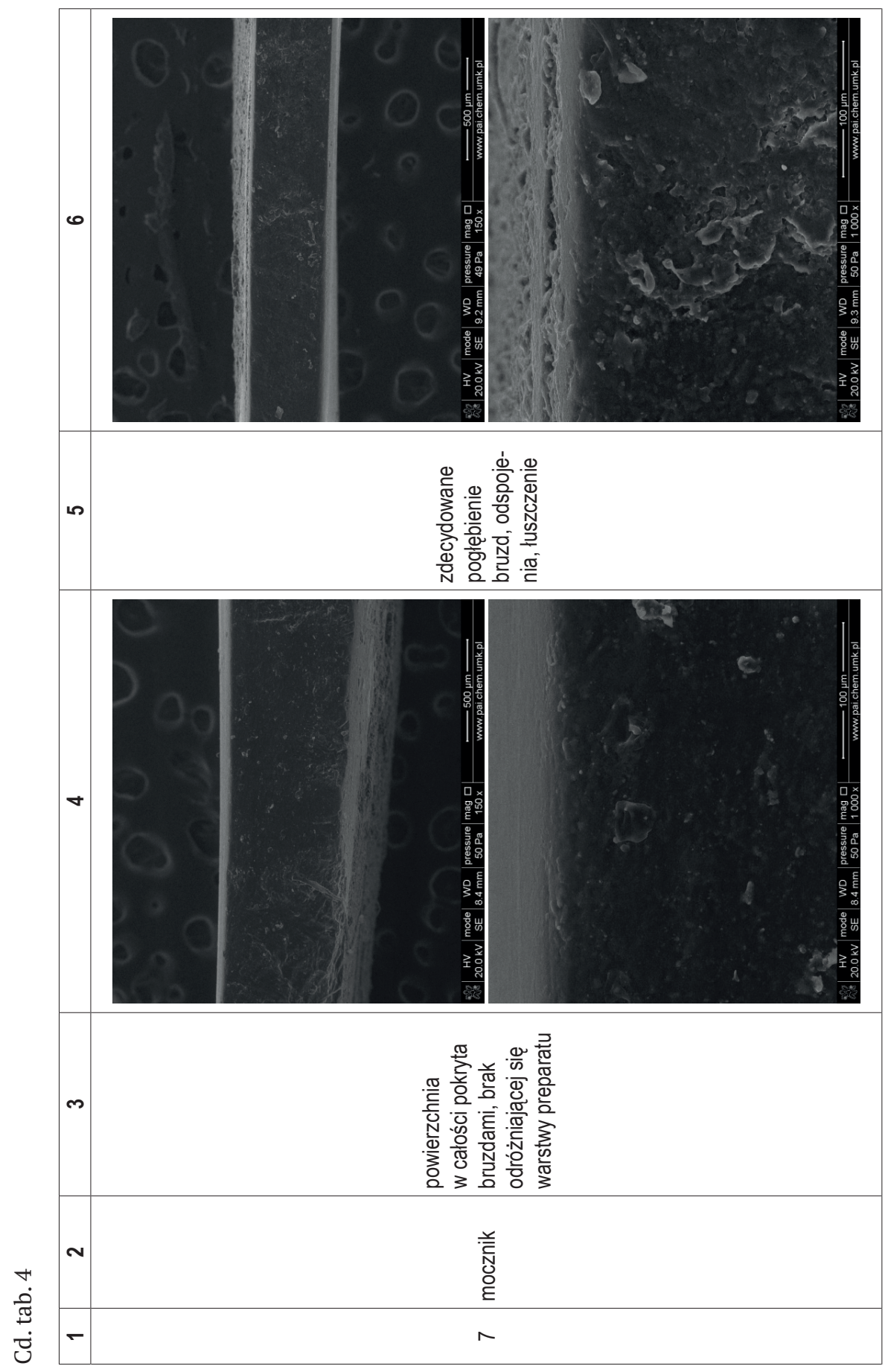




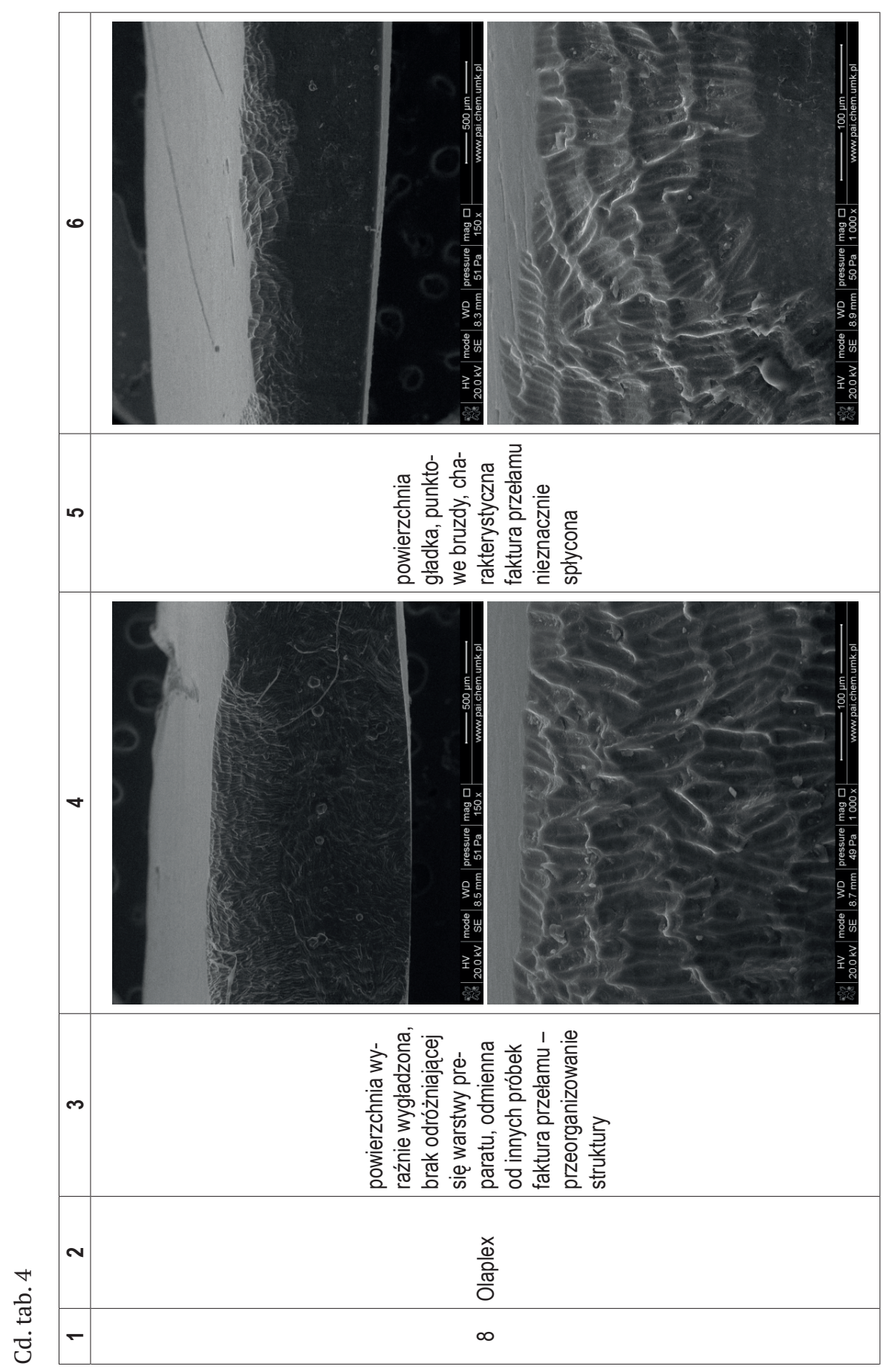




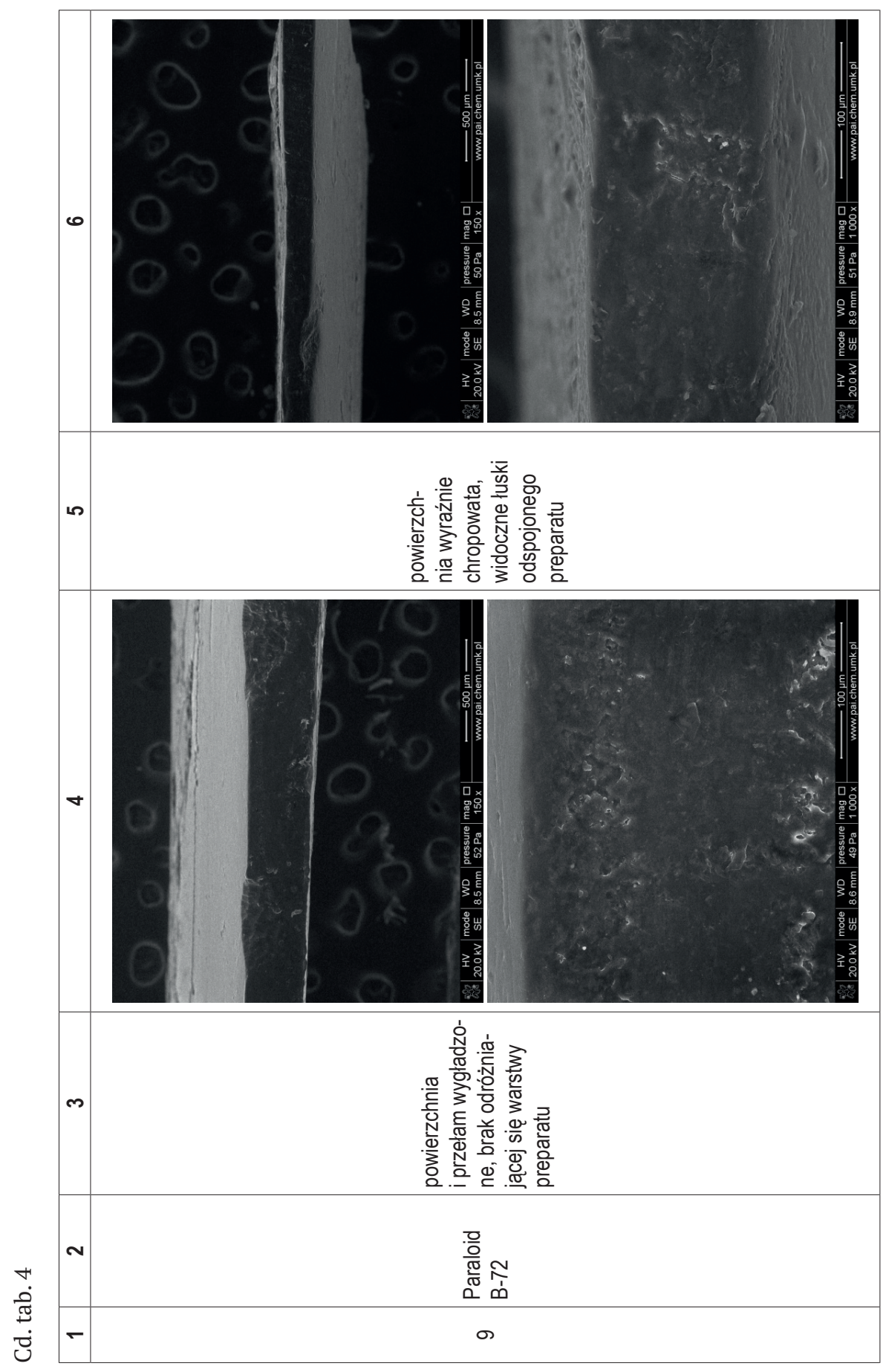


Obrazowanie skaningowym mikroskopem elektronowym umożliwiło analizę powłoki ochronnej utworzonej przez preparaty na powierzchni próbek oraz ich wpływu na strukturę (tabela 4). Olej arganowy jako jedyny uformował widoczną, odróżniającą się od szylkretu chropowatą warstwę równomiernie pokrywającą całą powierzchnię, która jednak nie zachowała się po działaniu komory klimatycznej. Przy zastosowaniu oleju bursztynowego i keratyny hydrolizowanej zaobserwowano na próbkach nieznaczne ilości preparatu. Paraloid B-72 pod wpływem zmiennych warunków wilgotnościowych odspoił się od szylkretu budując powłokę z łusek. Na przełamie płytki szylkretowej pokrytej środkiem Olaplex pojawiły się wyraźne zmiany strukturalne, tworzące charakterystyczną fakturę utrzymującą się również po próbach klimatycznych. Największe wygładzenie powierzchni odnotowano na próbkach pokrytych naturalnymi olejami roślinnymi.

\section{Mikroskopia sił atomowych}

Zmiany chropowatości powierzchni zarejestrowano na rysunkach 1-5 oraz w tabeli 5 . 

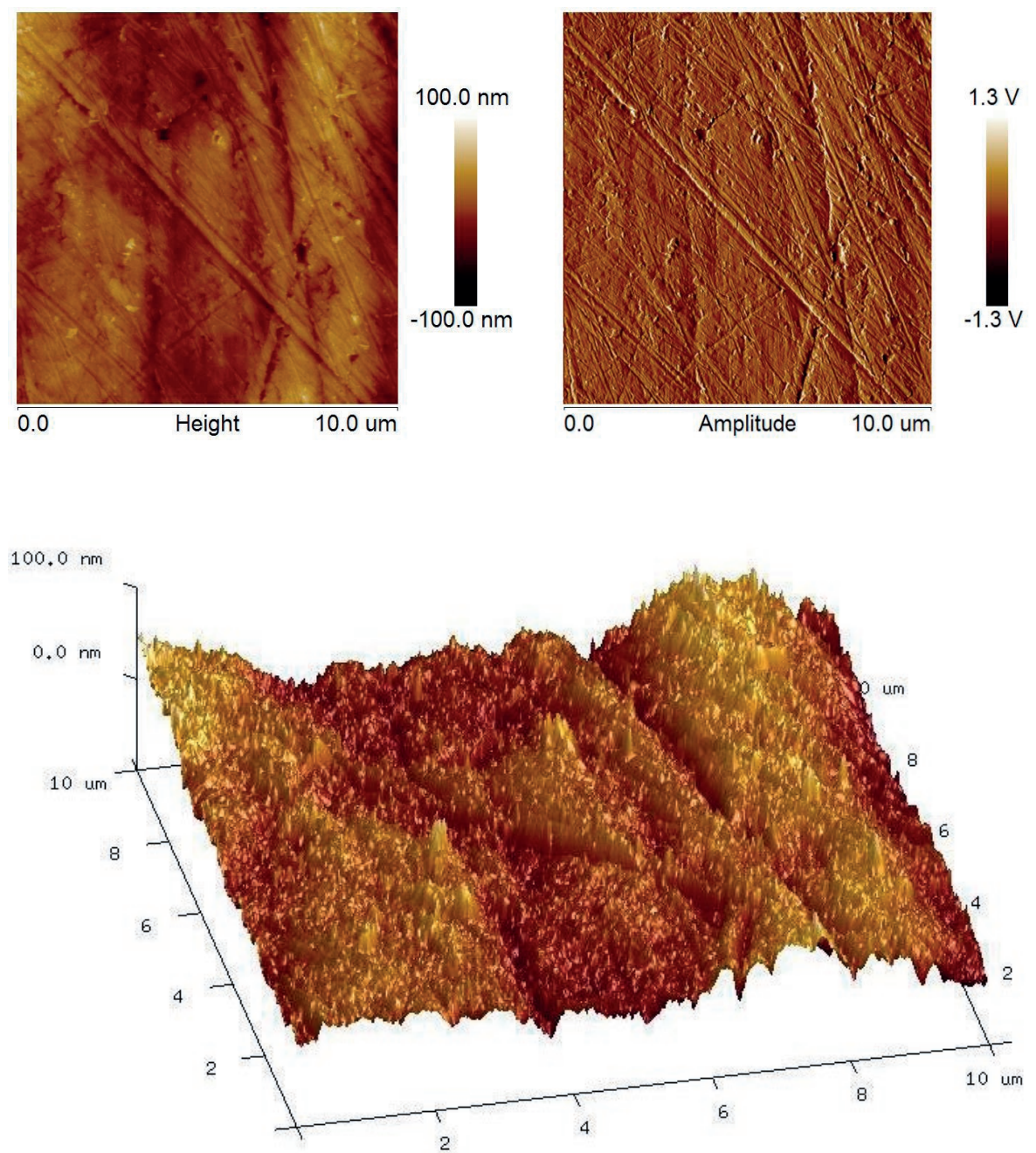

Rys. 1. Obrazowanie AFM wzorca szylkretu. Rys. Grażyna Szczepańska 

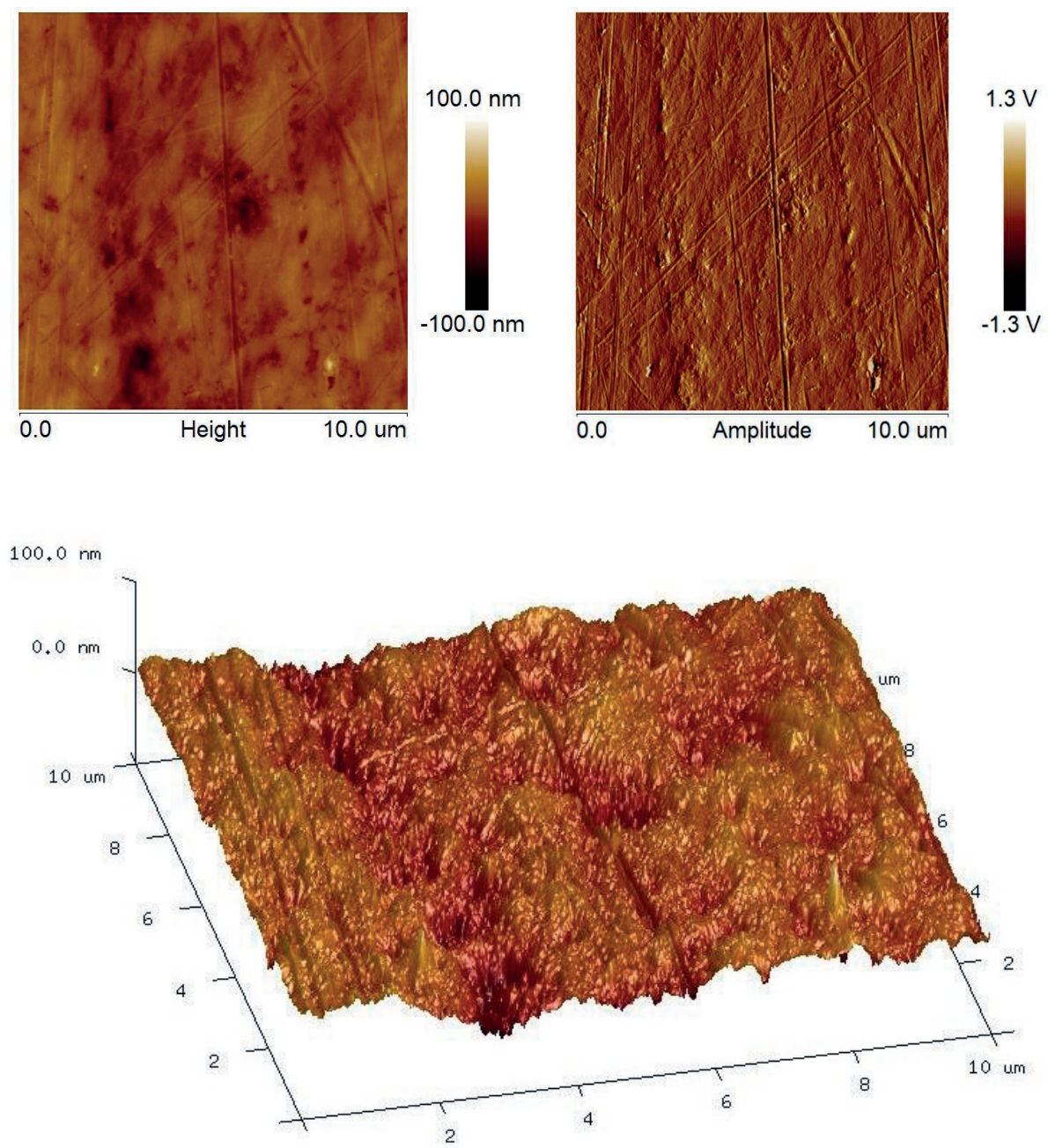

Rys. 2. Obrazowanie AFM szylkretu impregnowanego olejem migdałowym. Rys. Grażyna Szczepańska 

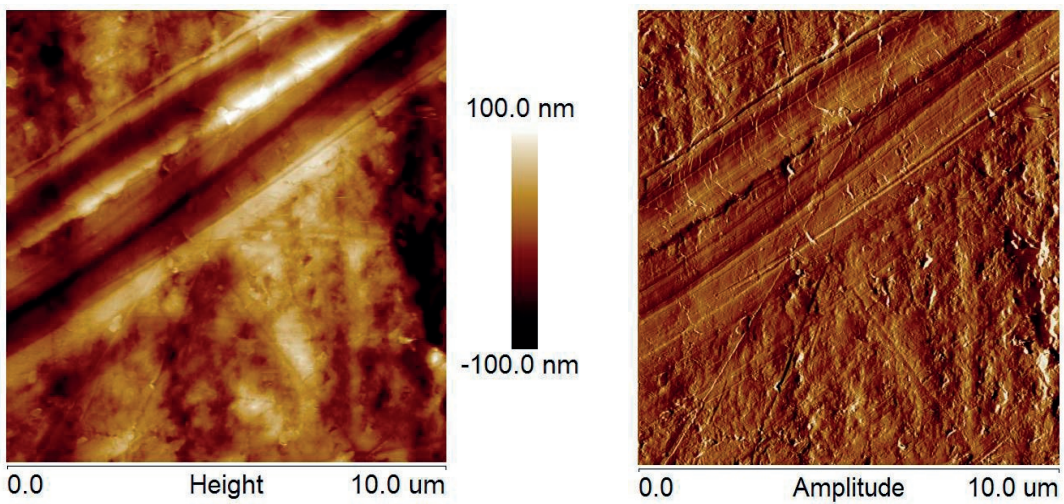

$100.0 \mathrm{~nm}$
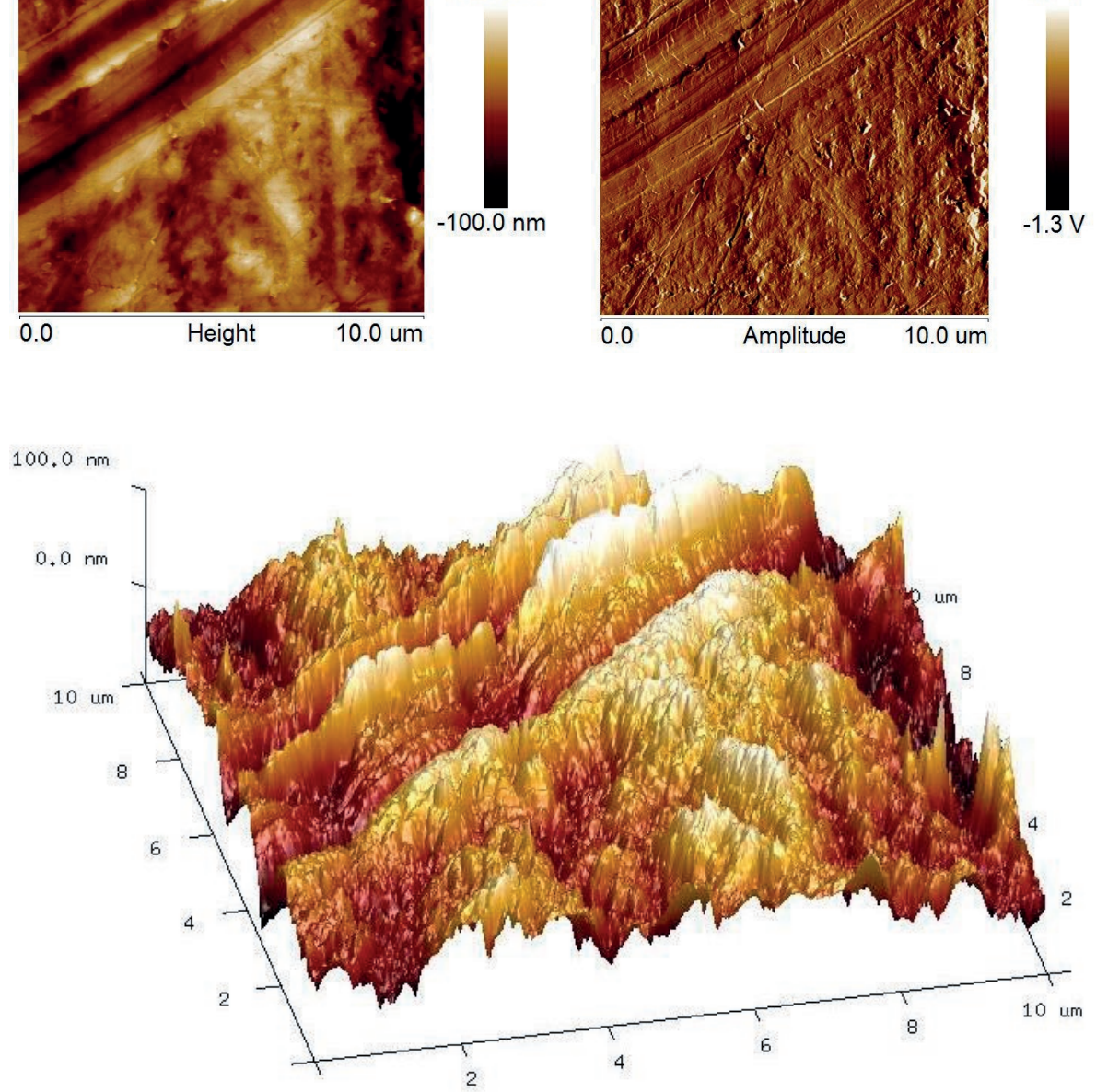

Rys. 3. Obrazowanie AFM szylkretu impregnowanego olejem arganowym. Rys. Grażyna Szczepańska 

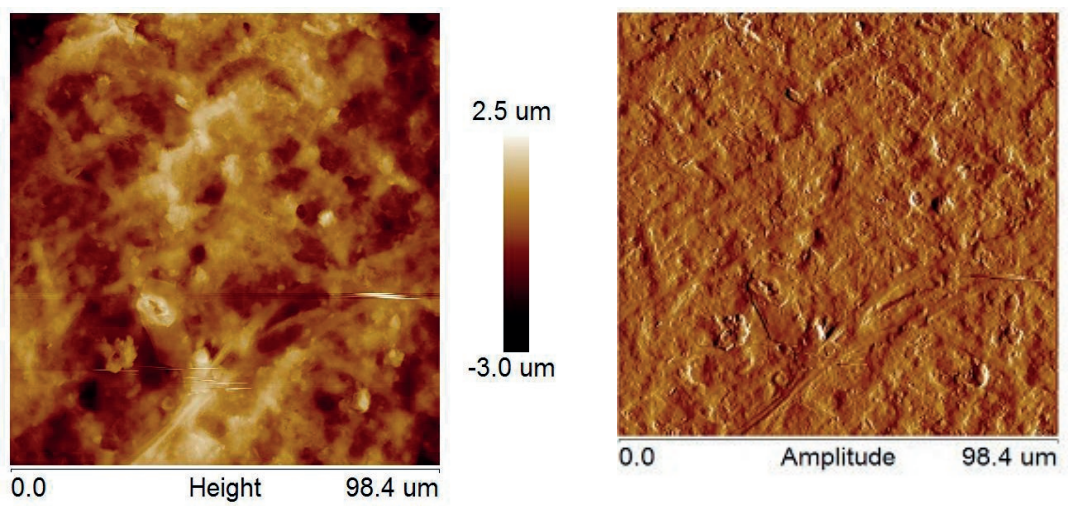

$2.5 \mathrm{~V}$

$-3.0 \mathrm{~V}$

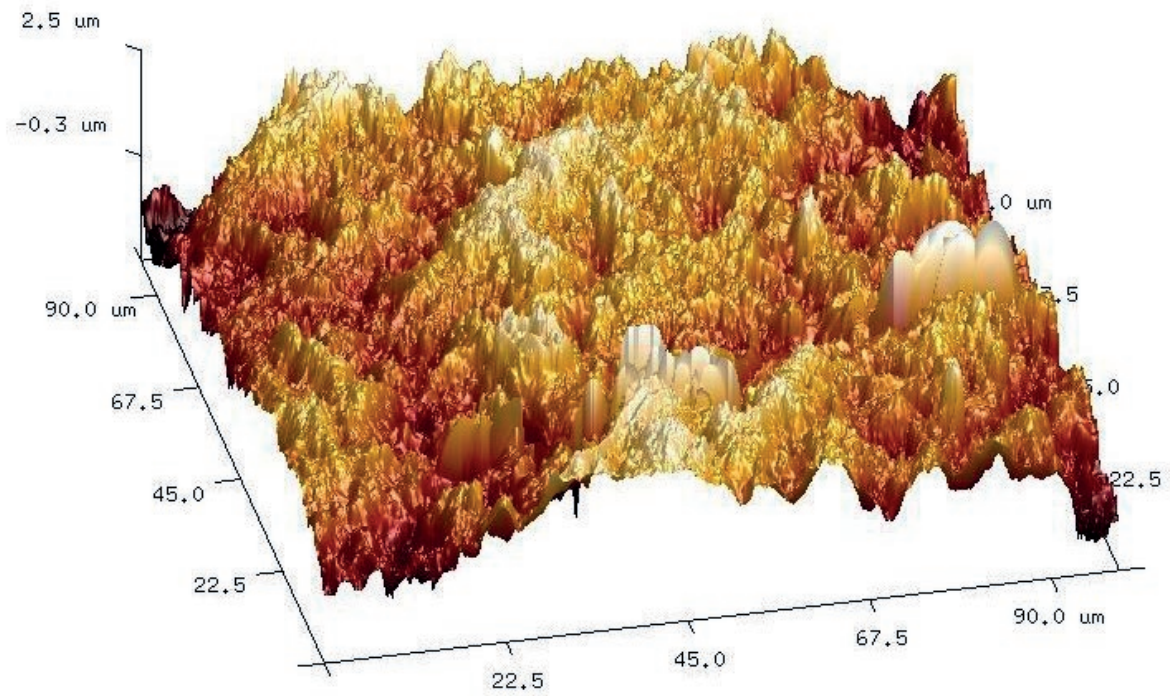

Rys. 4. Obrazowanie AFM wzorca łuski żółwia. Rys. Janusz Strzelecki 

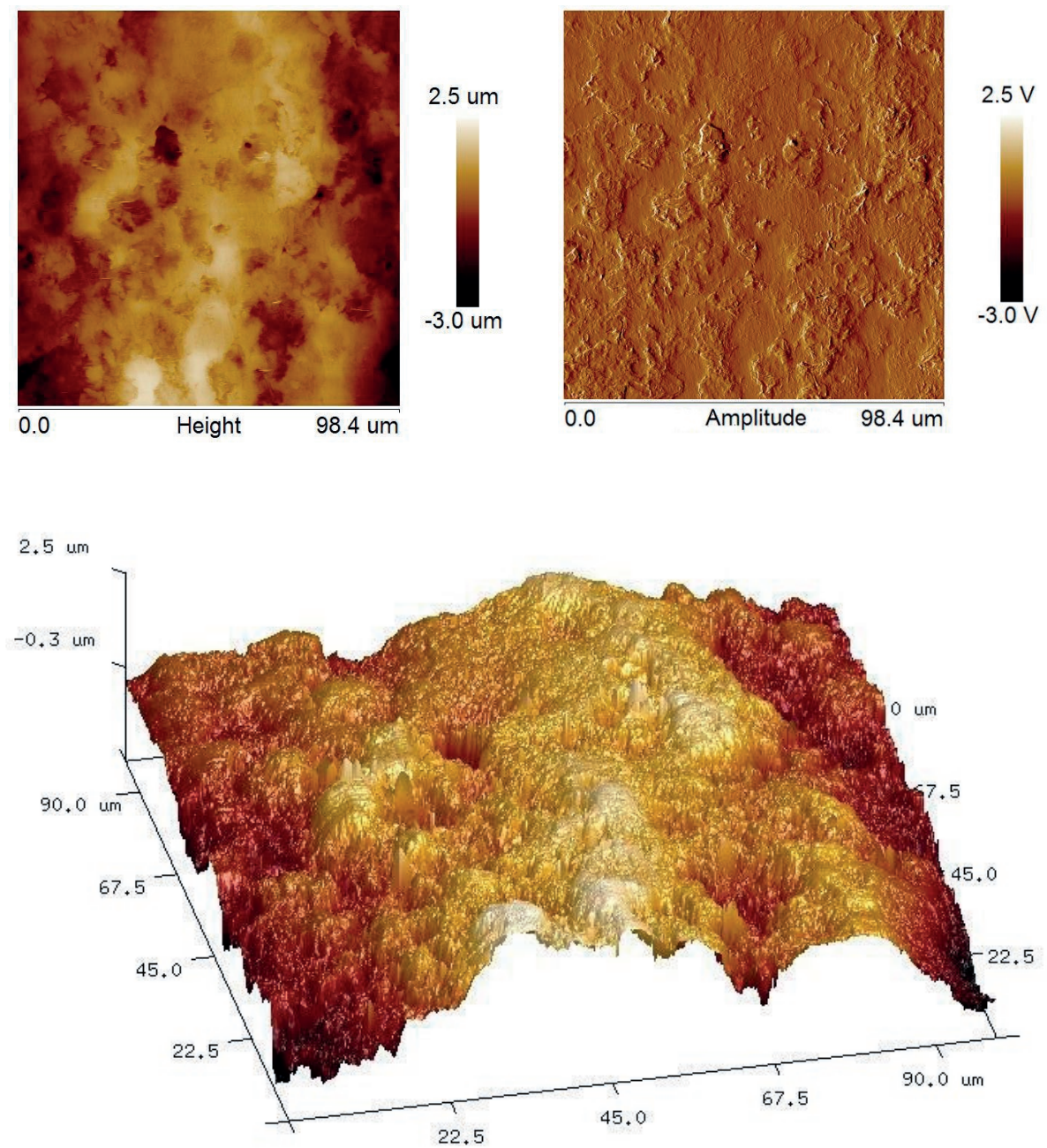

Rys. 5. Obrazowanie AFM łuski żółwia impregnowanej olejem migdałowym. Rys. Janusz Strzelecki 
Za pomocą programu NanoScope Analysis obliczono wartości parametrów chropowatości średniej arytmetycznej $R_{\mathrm{a}} \mathrm{i}$ kwadratowej $R_{\mathrm{q}}$. Wyniki przedstawiono w tabeli 5 .

Tabela 5. Chropowatość próbek z szylkretu i łusek żółwia wodnego

\begin{tabular}{|c|c|c|c|c|c|c|c|}
\hline \multirow{4}{*}{ Lp. } & \multirow{4}{*}{$\begin{array}{l}\text { Próbka / } \\
\text { preparat }\end{array}$} & \multicolumn{6}{|c|}{ Chropowatość } \\
\hline & & \multicolumn{3}{|c|}{$\mathrm{Rq}$} & \multicolumn{3}{|c|}{$\mathrm{R}_{\mathrm{a}}$} \\
\hline & & \multicolumn{3}{|c|}{ rozmiar skanu } & \multicolumn{3}{|c|}{ rozmiar skanu } \\
\hline & & $10 \mu \mathrm{m}$ & $5 \mu \mathrm{m}$ & $1 \mu \mathrm{m}$ & $10 \mu \mathrm{m}$ & $5 \mu \mathrm{m}$ & $1 \mu \mathrm{m}$ \\
\hline 1 & szylkret & $18,1 \mathrm{~nm}$ & $11,8 \mathrm{~nm}$ & $8,74 \mathrm{~nm}$ & $13,3 \mathrm{~nm}$ & $8,95 \mathrm{~nm}$ & $6,91 \mathrm{~nm}$ \\
\hline 2 & $\begin{array}{c}\text { szylkret / } \\
\text { olej migdałowy }\end{array}$ & $14,6 \mathrm{~nm}$ & $8,98 \mathrm{~nm}$ & $7,13 \mathrm{~nm}$ & $11,2 \mathrm{~nm}$ & $7,11 \mathrm{~nm}$ & $6,0 \mathrm{~nm}$ \\
\hline \multirow[t]{3}{*}{3} & $\begin{array}{c}\text { szylkret / } \\
\text { olej arganowy }\end{array}$ & $40,7 \mathrm{~nm}$ & $30,1 \mathrm{~nm}$ & $13,3 \mathrm{~nm}$ & $31,0 \mathrm{~nm}$ & $23,1 \mathrm{~nm}$ & $11,1 \mathrm{~nm}$ \\
\hline & & \multicolumn{3}{|c|}{ rozmiar skanu } & \multicolumn{3}{|c|}{ rozmiar skanu } \\
\hline & & $100 \mu \mathrm{m}$ & & $50 \mu \mathrm{m}$ & $100 \mu \mathrm{m}$ & & $50 \mu \mathrm{m}$ \\
\hline 4 & łuska żółwia & $797 \mathrm{~nm}$ & & $463 \mathrm{~nm}$ & $626 \mathrm{~nm}$ & & $367 \mathrm{~nm}$ \\
\hline 5 & $\begin{array}{l}\text { łuska żółwia / } \\
\text { olej migdałowy }\end{array}$ & $855 \mathrm{~nm}$ & & $406 \mathrm{~nm}$ & $671 \mathrm{~nm}$ & & $305 \mathrm{~nm}$ \\
\hline
\end{tabular}

Kilka pierwszych przeprowadzonych analiz i oznaczeń chropowatości powierzchni próbek dało duży rozrzut wyników, które nie odzwierciedlały rzeczywistego stanu. Powodem tego były mały obszar skanowania przy dużym zróżnicowaniu powierzchni oraz brak powtarzalności badania obszaru przed nasyceniem, po tym zabiegu oraz po wywarciu wpływu przez zmienne warunki klimatyczne. Z tych względów zaniechano dalszych oznaczeń z wykorzystaniem tej metody badawczej. 


\section{Podsumowanie}

Najlepszym działaniem zabezpieczającym szylkret oraz łuski żółwia wykazały się oleje roślinne: migdałowy, arganowy i rycynowy. Dobrze impregnują powierzchnię, przy czym część jej defektów, takich jak zarysowania, zmatowienia, staje się nieobserwowalna, powodując wzrost nasycenia barwnego i transparentności tych materiałów. Korzystnie wpływają również na wzrost elastyczności keratyny. Wymienione efekty utrzymują się po przeprowadzeniu prób klimatycznych. Na szczególną uwagę w tej grupie preparatów zasługuje olej arganowy, który dodatkowo utworzył na szylkrecie równomierną powłokę ochronną, widoczną dopiero przy obrazowaniu SEM.

Analiza SEM przełamu płytki szylkretowej poddanej działaniu preparatu Olaplex wykazała przebudowę struktury tego materiału. Olaplex w największym stopniu zwiększył elastyczność szylkretu, ponadto może pozytywnie wpływać na bardzo zniszczoną keratynę, regenerując ją.

Pozostałe badane produkty przyczyniły się w różnym stopniu do spadku elastyczności próbek, nie spełniają więc oczekiwań stawianych preparatom zabezpieczającym. Zastosowanie niektórych z nich może być jednak uzasadnione przy wystąpieniu innych, specyficznych form zniszczeń obiektów zabytkowych wykonanych z szylkretu. Paraloid B-72 może skutecznie podklejać rozwarstwienia. Olej bursztynowy daje możliwość wzmocnienia barwy elementów, które pod wpływem czynników niszczących uległy zabieleniom i utraciły charakterystyczną złocistobrązową barwę. Mocznik, dzięki swojej zdolności wiązania cząsteczek wody, może mógłby być wykorzystywany do przywrócenia równowagi wilgotnościowej obiektów szczególnie przesuszonych i zdeformowanych, lecz potwierdzenie jego skuteczności w tym zakresie wymagałoby dalszych badań.

\section{Konserwacja skorupy żółwia szylkretowego}

Dobre rezultaty w zabezpieczaniu szylkretu, jakie osiągnięto dzięki olejom pochodzenia roślinnego, skłoniły do zastosowania tego rozwiązania w pracach konserwatorskich przy karapaksie szylkretowego żółwia należącego do zbiorów Wydziału Biologii i Ochrony Środowiska UMK w Toruniu. Awers puklerza żółwia był pokryty grubą powłoką pożółkłego lakieru akrylowego (fot. 1: A), zacieki lakieru znalazły się również na jego spodniej stronie. 


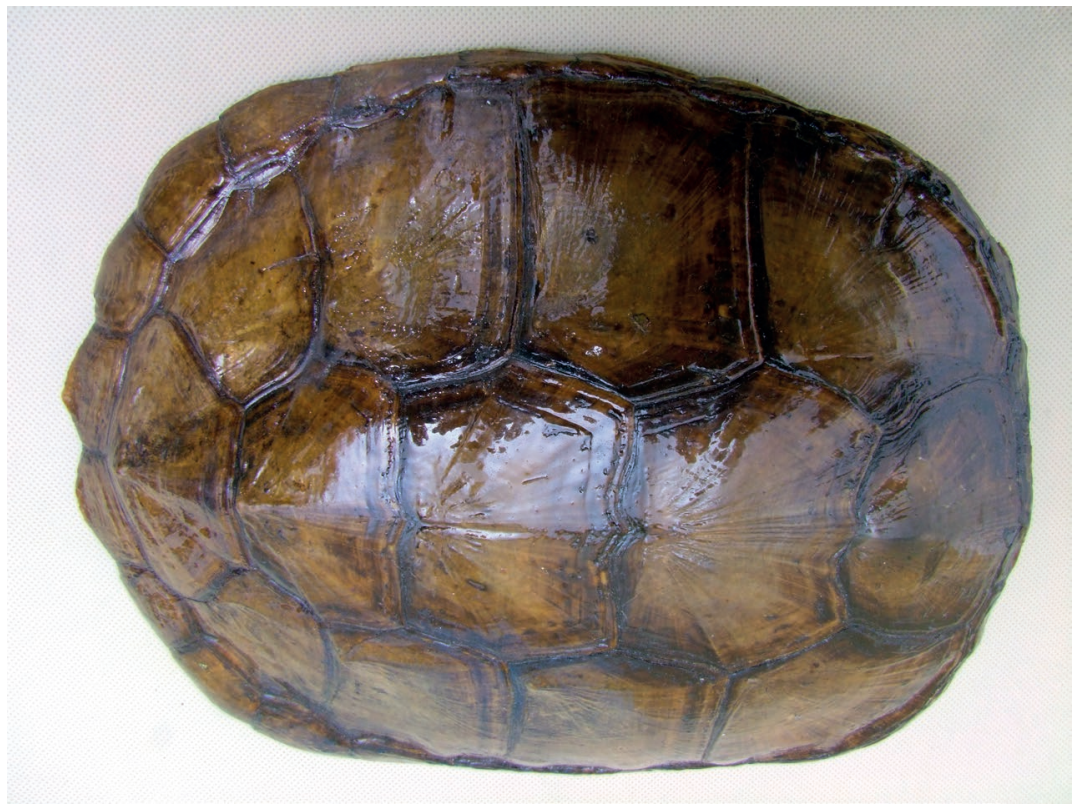

A

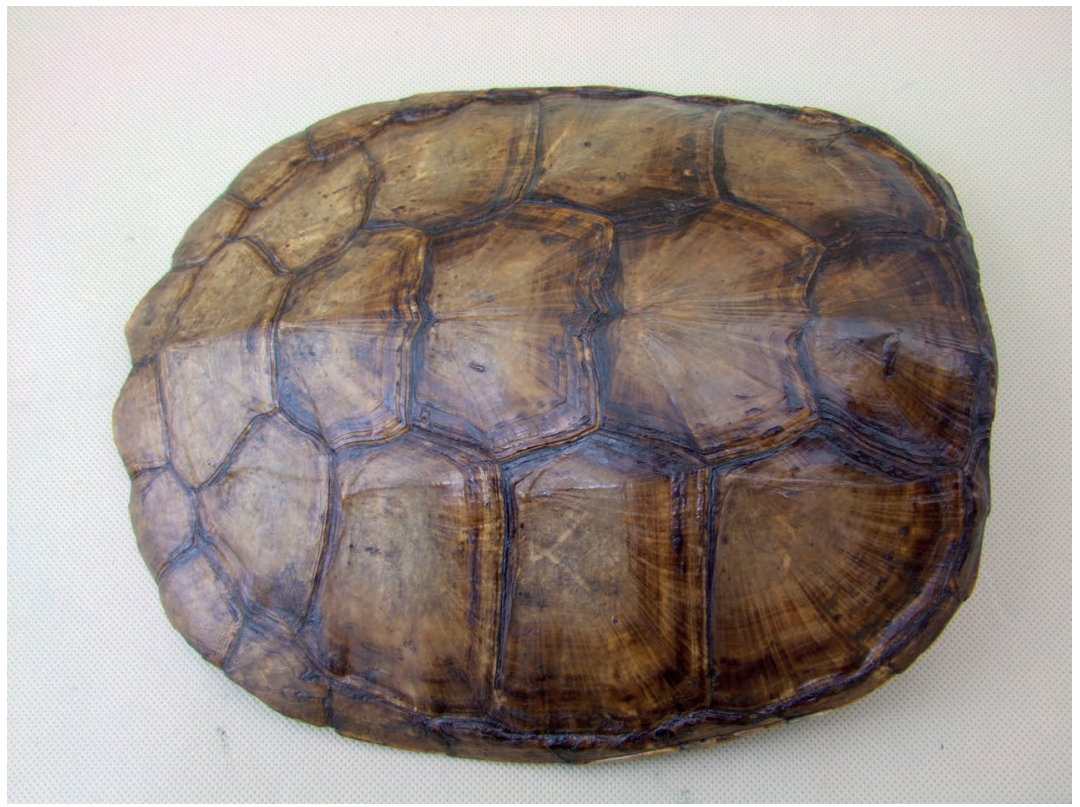

Fot. 1. Wydział Biologii i Ochrony Środowiska UMK w Toruniu. Karapaks żółwia szylkretowego. Fot. Alina Tomaszewska-Szewczyk A - stan przed konserwacją; B - stan po konserwacji 
W zagłębieniach między tarczkami zalegały zabrudzenia. Pod wpływem działania czynników mechanicznych powstały spękania i złuszczenia.

Należało zdjąć nieestetyczną powłokę z karapaksu, podkleić rozwarstwienia oraz zabezpieczyć powierzchnię obiektu. Pierwszym etapem prac było usunięcie lakieru wraz z zanieczyszczeniami, zalegającymi głównie w szczelinach między tarczkami. Zastosowano do tego rozpuszczalniki organiczne. Początkowo grubą powłokę zmywano acetonem, natomiast w kontakcie z karapaksem używano już tylko toluenu oraz ksylenu. Takie postępowanie miało na celu niedopuszczenie do nadmiernego przesuszenia keratyny, które prowadziłoby do utraty elastyczności materiału. W trakcie oczyszczania obiekt regularnie obserwowano w świetle UV, co umożliwiło całkowite usunięcie pozostałości lakieru. Wszelkie spękania i odspojenia wypełniono metodą iniekcji 10-procentowym roztworem Paraloidu B-72 w ksylenie. Do zabezpieczenia powierzchni skorupy wytypowano olej arganowy. Przed nałożeniem olej podgrzano w kąpieli wodnej do temperatury około $35^{\circ} \mathrm{C}$, następnie pokryto nim awers karapaksu używając miękkiego pędzla. Zabieg powtórzono po dwóch dobach. Nadmiar oleju usunięto bawełnianą tkaniną.

Przeprowadzone zabiegi przyniosły zadowalający efekt. Powierzchnia eksponatu jest jednolita, o lekkim, naturalnym połysku (fot. 1: B).

\section{Bibliografia}

Ciabach, Jerzy. „Właściwości i zastosowanie Paraloidu B-72”. Ochrona Zabytków 35 (1982): 111-112.

Combs, Gerald F., Jr. The Vitamins. Fundamental Aspect in Nutrition and Health. London: Academic Press, 2012.

Cronyn, Janet M. The Elements of Archeological Conservation. London: Routledge, 2001. Hilali, Miloudi, Zoubida Charrouf, Abd E. A. Soulhi, Larbi Hachimi, i Dominique Guillaume. "Influence of Origin and Extraction Method on Argan Oil Physico-Chemical Characteristics and Composition”. Journal of Agricultural and Food Chemistry 53 (2005): 2081-2087. DOI 10.1021/jf040290t.

Karczmarek, Halina, Ryszard Czajka, Marek Nowicki, i Dagmara Ołdak. „Badania polimerów z wykorzystaniem metody mikroskopii sił atomowych”. Polimery 47 (2002): 775-783. Dostęp 20 lutego 2017.

Lorencini, Márcio, Carla A. Brohem, Gustavo C. Dieamant, Nilson I. T. Zanchin, i Howard I. Maibach. "Active Ingredients Against Human Epidermal Aging”. Ageing Research Reviews 15 (2014): 100-115. http://dx.doi.org/10.1016/j.arr.2014.03.002. 
Manca, Maria L., Pietro Matricardi, Claudia Cencetti, Josè E. Peris, Virginia Melis, Claudia Carbone, Elvira Escribano, Marco Zaru, Anna M. Fadda, i Maria Manconi. "Combination of Argan Oil and Phospholipids for the Development of Aneffective Liposome-Like Formulation Able to Improve Skin Hydration and Allantoin Dermal Delivery”. International Journal of Pharmaceutics 505 (2016): 204-211. http://dx.doi. org/10.1016/j.ijpharm.2016.04.008.

Mandalari, Giuseppina, Antonio Tomaino, Teresita Arcoraci, Maria Martorana, Vincenzo Lo Turco, Francesco Cacciola, Gillian T. Rich, Carlo Bisignano, Antonella Saija, Paola Dugo, Kathryn L. Cross, Mary L. Parker, Keith W. Waldron, i Martin S. J. Wickham. „Characterization of Polyphenols, Lipids and Dietary Fibre from Almond Skins (Amygdalus communis L.)”. Journal of Food Composition and Analysis 23, no. 2 (2010): 166-174. DOI: 10.1016/j.jfca.2009.08.015.

Nangbes, Jacobs G., Barnabas J. Nvau, Wufem M. Buba, i Adamu N. Zukdimma. "Extraction and Characterization of Castor (Ricinus Communis) Seed Oil”. The International Journal of Engineering and Science 2, no. 9 (2013): 105-109. theijes.com/papers/v2-i9/ Part.3/P029301050109.pdf. Dostęp 20 lutego 2017.

Nanotechnologia, kosmetyki, chemia supramolekularna, red. Grzegorz Schroeder. Kostrzyń: Wydawnictwo Cursiva, 2010.

Plenderleith, H[arold] J. The Conservation of Antiquities and Works of Art. Treatment, Repair, and Restoration. London: Oxford University Press, 1962.

Podgórski, Andrzej, Alina Tomaszewska-Szewczyk. „Szylkret, bioorganiczny materiał w rzemiośle artystycznym - zagadnienia z zakresu materiałoznawstwa, technologii i stosowanych technik dekoracyjnych oraz niszczenia”. Acta Universitatis Nicolai Copernici, Zabytkoznawstwo i Konserwatorstwo 46 (2015): 449-470. DOI: http:// dx.doi.org/10.12775/AUNC_ZiK.2015.018.

Ramos-e-Silva, Marcia, Livia R. Celem, Stella Ramos-e-Silva, i Ana Paula Fucci-daCosta. "Anti-Aging Cosmetics: Facts and Controversies". Clinics in Dermatology 31 (2013): 750-758. http://dx.doi.org/10.1016/j.clindermatol.2013.05.013.

Robbins, Clarence R. Chemical and Physical Behavior of Human Hair. Berlin, Heidelberg: Springer-Verlag, 2012.

Ślesiński, Władysław. Konserwacja zabytków sztuki. T. 3 Rzemiosło artystyczne. Warszawa: Wydawnictwo Arkady, 1995.

Vidler, Karen. "Conservation of a tortoiseshell book cover”. Conservation Journal

Summer 2005 Issue 50. http://www.vam.ac.uk/content/journals/conservation-journal/ issue-50/conservation-of-a-tortoiseshell-book-cover/

Yusuf, A. K., A. P. Mamza, A. S. Ahmed, i U. Agunwa. "Extraction and Characterization of Castor Seed Oil from Wild Ricinus communis Linn”. International Journal of Science, Envorinment and Technology 5 (2015): 1392-1395. www.ijset.net/journal/786.pdf. Dostęp 20 lutego 2017. 